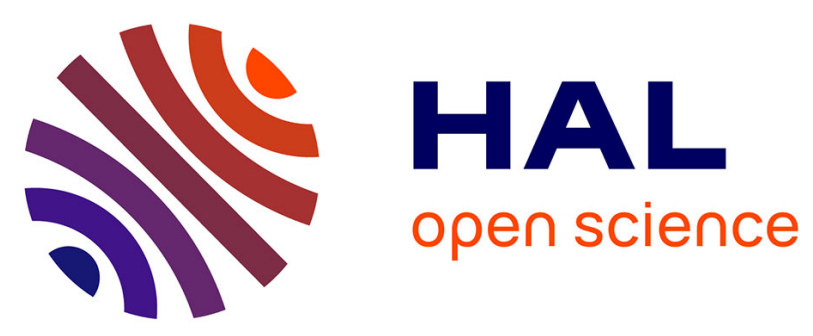

\title{
Quaternary seismo-tectonic activity of the Polochic Fault, Guatemala
}

\author{
Christine Authemayou, Gilles Y. Brocard, Christian Teyssier, Barbara Suski, \\ Beatriz Cosenza, Sergio Moran-Ical, Claussen Walther Gonzalez-Veliz, Miguel \\ Angel Aguilar-Hengstenberg, Klaus Holliger
}

\section{To cite this version:}

Christine Authemayou, Gilles Y. Brocard, Christian Teyssier, Barbara Suski, Beatriz Cosenza, et al.. Quaternary seismo-tectonic activity of the Polochic Fault, Guatemala. Journal of Geophysical Research, 2012, 117, pp.B07403. 10.1029/2012JB009444 . insu-00732137

\section{HAL Id: insu-00732137 https://hal-insu.archives-ouvertes.fr/insu-00732137}

Submitted on 14 Mar 2013

HAL is a multi-disciplinary open access archive for the deposit and dissemination of scientific research documents, whether they are published or not. The documents may come from teaching and research institutions in France or abroad, or from public or private research centers.
L'archive ouverte pluridisciplinaire HAL, est destinée au dépôt et à la diffusion de documents scientifiques de niveau recherche, publiés ou non, émanant des établissements d'enseignement et de recherche français ou étrangers, des laboratoires publics ou privés. 


\title{
Quaternary seismo-tectonic activity of the Polochic Fault, Guatemala
}

\author{
Christine Authemayou, ${ }^{1,2}$ Gilles Brocard, ${ }^{1,3}$ Christian Teyssier, ${ }^{1,4}$ Barbara Suski, ${ }^{5}$ \\ Beatriz Cosenza, ${ }^{6}$ Sergio Morán-Ical, ${ }^{7}$ Claussen Walther González-Véliz, ${ }^{7}$ \\ Miguel Angel Aguilar-Hengstenberg, ${ }^{7}$ and Klaus Holliger ${ }^{5}$ \\ Received 15 May 2012; accepted 18 May 2012; published 6 July 2012.
}

[1] The Polochic-Motagua fault system is part of the sinistral transform boundary between the North American and Caribbean plates in Guatemala and the associated seismic activity poses a threat to $\sim 70 \%$ of the country's population. The aim of this study is to constrain the Late Quaternary activity of the Polochic fault by determining the active structure geometry and quantifying recent displacement rates as well as paleo-seismic events. Slip rates have been estimated from offsets of Quaternary volcanic markers and alluvial fan using in situ cosmogenic ${ }^{36} \mathrm{Cl}$ exposure dating. Holocene left-lateral slip rate and Mid-Pleistocene vertical slip rate have been estimated to $4.8 \pm 2.3 \mathrm{~mm} / \mathrm{y}$ and $0.3 \pm 0.06 \mathrm{~mm} / \mathrm{y}$, respectively, on the central part of the Polochic fault. The horizontal slip rate is within the range of longer-term geological slip rates and short-term GPS-based estimates. In addition, the non-negligible vertical motion participates in the uplift of the block north of the fault and seems to be a manifestation of the regional, far-field stress regime. We excavated the first trench for paleo-seismological study on the Polochic fault in which we distinguish four large paleo-seismic events since 17 ky during which the Polochic fault ruptured the ground surface.

Citation: Authemayou, C., G. Brocard, C. Teyssier, B. Suski, B. Cosenza, S. Morán-Ical, C. W. González-Véliz, M. A. AguilarHengstenberg, and K. Holliger (2012), Quaternary seismo-tectonic activity of the Polochic Fault, Guatemala, J. Geophys. Res., 117, B07403, doi:10.1029/2012JB009444.

\section{Introduction}

[2] Transform boundaries affecting the continental lithosphere have the potential of generating major destructive earthquakes, such as, for example, the Landers earthquake in 1992 along the San Andreas fault in the western USA [Massonnet et al., 1993] and the Izmit earthquake in 1999 along the North Anatolian fault in Turkey [Reilinger et al., 2000]. Generally, such transform boundaries are comprised of parallel and relaying segments, each of which

\footnotetext{
${ }^{1}$ Institute of Geology and Paleontology, University of Lausanne, Lausanne, Switzerland.

${ }^{2}$ Now at Laboratoire Domaines océaniques, UMR 6538 - IUEM, Université de Brest, CNRS, Plouzané, France.

${ }^{3}$ Now at Department of Earth and Environmental Science, University of Pennsylvania, Philadelphia, Pennsylvania, USA.

${ }^{4}$ Now at Department of Earth Sciences, University of Minnesota, Minneapolis, Minnesota, USA.

${ }^{5}$ Institute of Geophysics, University of Lausanne, Lausanne, Switzerland.

${ }^{6}$ Physics Department, Faculty of Engineering, University of San Carlos de Guatemala, Guatemala City, Guatemala.

${ }^{7}$ University of San Carlos de Guatemala, Centro Universitario del Noreste, Cobán, Guatemala.

Corresponding author: C. Authemayou, Institute of Geology and Paleontology, University of Lausanne, CH-1015 Lausanne, Switzerland. (christine.authemayou@univ-brest.fr)

C2012. American Geophysical Union. All Rights Reserved. 0148-0227/12/2012JB009444
}

accommodates a fraction of interplate motion. Seismotectonic analyses of the individual fault strands are therefore necessary to evaluate the seismic hazard associated with the transform boundary as a whole.

[3] The east-west trending Polochic-Motagua fault system in Guatemala delineates the transform boundary between the North American and Caribbean plates (Figure 1). The fault system connects eastward with the Cayman oceanic spreading center in the Caribbean Sea [Pindell et al., 2005]. To the west, theses faults splay over into the diffuse Cocos-CaribbeanNorth-American triple junction [Plafker, 1976; Gordon and Muehlberger, 1994; Guzmán- Speziale and Meneses-Rocha, 2000; Guzmán-Speziale, 2010; Lyon-Caen et al., 2006; Authemayou et al., 2011]. The Motagua and Polochic faults are the dominant tectonic features of this system. The southern, smoothly curved Motagua fault stretches $\sim 300 \mathrm{~km}$ from Chichicastenango to Puerto Barrios (Figure 1). The Polochic fault is located $\sim 50 \mathrm{~km}$ further north, has an inland extension of $\sim 500 \mathrm{~km}$, and its overall trace is straighter than that of the Motagua fault. The most conspicuous secondary faults of the system are the East-striking Ixcán fault, north of the Polochic fault [Guzmán-Speziale, 2010], and the Eaststriking Jocotán-Chamelecón fault south of the Motagua fault [Gordon and Muehlberger, 1994] (Figure 1).

[4] Both the Polochic and Motagua faults exhibit morphological and historical evidence of ongoing seismic activity [Kupfer and Godoy, 1967; Schwartz et al., 1979; 


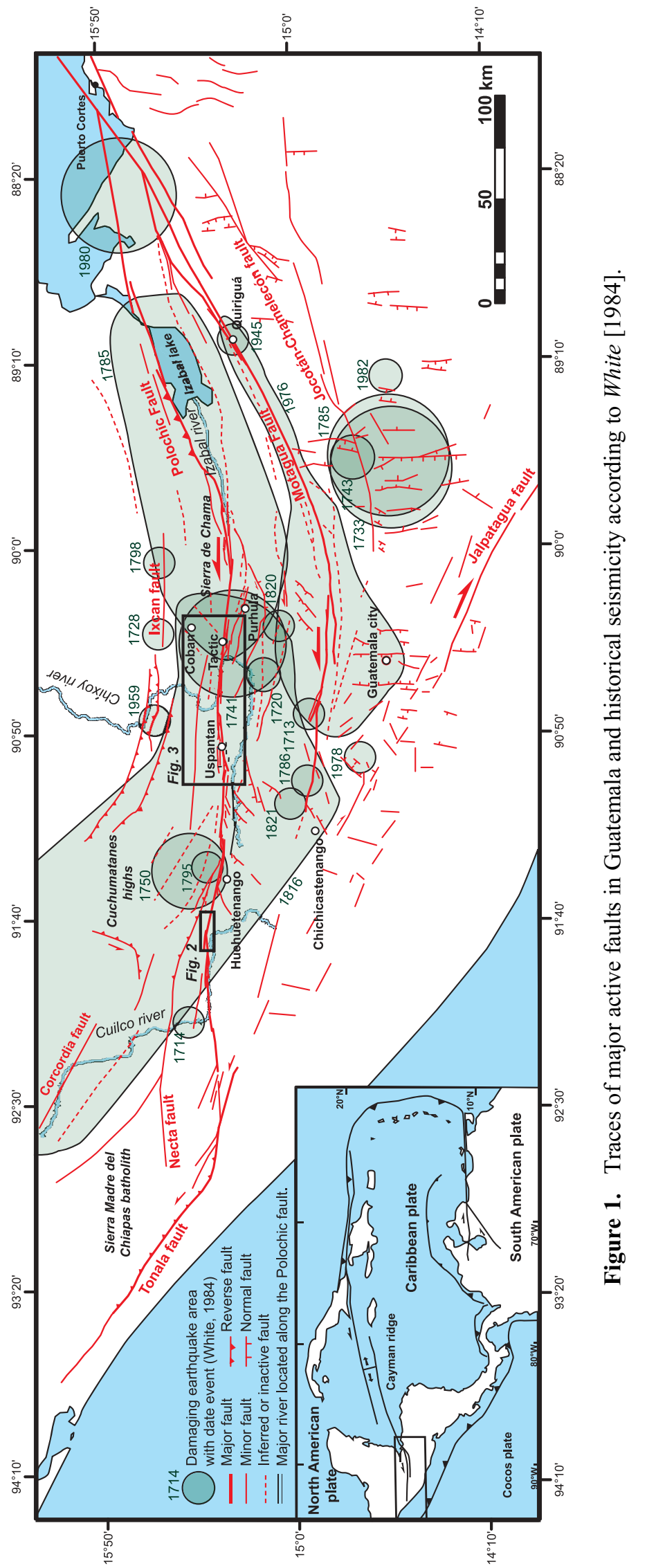


White, 1984, 1985; White and Harlow, 1993; Kovach and Nur, 2006; Franco et al., 2009]. The Motagua fault generated an earthquake of magnitude 7.5 in 1976, which claimed $\sim 23,000$ lives, and evidence for at least one major paleoearthquake was found in the 1100-year-old Mayan city of Quiriguá, located next to the active trace of the fault [Kovach and Nur, 2006]. GPS measurements fitted to a model of elastic deformation suggest that the Motagua fault accommodates $\sim 75 \%$ of interplate motion [Lyon-Caen et al., 2006]. Although not moving as fast as the Motagua fault, the Polochic fault has a denser record of historical seismicity. Reports dating back to the onset of Spanish colonization in $1525 \mathrm{AD}$ suggest that during the past five centuries the Polochic fault generated many earthquakes of magnitude 5 to 6 and three large earthquakes with magnitudes in excess of 7 in 1538, 1785, and 1816 AD (Figure 1) [White, 1984]. The Polochic fault is also a major regional discontinuity in the tectonic strain field, as it separates a shortening domain to the north from an extensive domain to the south [Ratschbacher et al., 2009; Authemayou et al., 2011]. Shortening in the north and extension in the south progressively absorb the overall plate motion, such that the slip rate along the Polochic-Motagua fault system decreases westward as it approaches the triple junction [Plafker, 1976; Burkart, 1983; Gordon and Muehlberger, 1994; Guzmán-Speziale and Meneses-Rocha, 2000; Lyon-Caen et al., 2006; Andreani et al., 2008; Witt et al., 2012].

[5] Recent displacements along the Polochic fault are documented by various stream offsets, some of which amounting to $\sim 1 \mathrm{~km}$ [Kupfer and Godoy, 1967; Schwartz et al., 1979; Dengo, 1982; Erdlac and Anderson, 1982]. So far, however, the Polochic fault lacks in-depth investigation of its seismic activity as well as an accurate quantification of its lateral slip rate during the Quaternary. Trench excavations for paleo-seismological studies started in 2007 along the Motagua fault (Cécile Lasserre, personal communication, 2012) and corresponding efforts are still ongoing along the Polochic Fault. The Polochic fault and some of its associated strands were recently explored by means of electrical resistivity tomography (ERT) imaging [Suski et al., 2010].

[6] In this paper, we present a morphotectonic study of recently displaced geologic and geomorphic markers to quantify the seismo-tectonic activity of the Polochic fault. Selected geomorphological markers were analyzed based on aerial stereoscopic photographs, and their age was determined using radiocarbon and cosmogenic ${ }^{36} \mathrm{Cl}$ surface exposure dating techniques. Ground deformation was investigated using paleo-stress inversion of kinematic indicators, ERT imaging, and trench excavation. We evaluate the lateral and vertical offsets along the central part of the Polochic fault and propose Late Quaternary slip rates by combining offset and age information. We also identify several Late Pleistocene seismic events in a paleo-seismological trench that was excavated through the Polochic fault.

\section{Tectonic Setting and Seismic Activity of the Polochic Fault}

\subsection{Slip Rate Estimates: Geological Evidence and GPS Measurements}

[7] The Caribbean-North-American interplate motion velocity has been inferred from slip vectors of earthquakes and marine magnetic anomalies and ranges from $11 \pm 6$ to $37 \pm 10$ mm/y [Jordan, 1975; Sykes et al., 1982; Stein et al., 1988]. The opening rate of the Cayman pull-apart spreading center, based on magnetic anomalies, is evaluated at 15$25 \mathrm{~mm} / \mathrm{y}$ since the Mid-Eocene [Rosencrantz et al., 1988; Leroy et al., 2000], with a proposed increase to $40 \pm 2 \mathrm{~mm} / \mathrm{y}$ between 6 and 2.4 My [Macdonald and Holcombe, 1978]. GPS measurements consistently indicate a present-day motion of 18-20 mm/y [Dixon, 1993; DeMets et al., 2000] that decreases to $12 \mathrm{~mm} / \mathrm{y}$ toward the NA-CA-Cocos triple junction [Lyon-Caen et al., 2006].

[8] GPS measurements coupled with an elastic-dislocation model suggest that the Polochic fault accommodates less than $25 \%$ of the total plate motion, with a maximum slip rate of $5 \mathrm{~mm} / \mathrm{y}$ in the east and a gradual decrease of the slip rate to zero near its western termination [Lyon-Caen et al., 2006]. Kupfer and Godoy [1967] observed Holocene left-lateral strike-slip offsets of up to $122 \mathrm{~m}$ in length, pointing to a maximum strike-slip velocity of $\sim 12 \mathrm{~mm} / \mathrm{y}$. Based on offset geological structures and ore deposits, Burkart [1978] estimated the total horizontal displacement on the Polochic fault to $135 \pm 5 \mathrm{~km}$. Burkart [1983] confirmed this value by retrodeforming and matching the regional drainage patterns across the fault. Deaton and Burkart [1984] compared clast assemblages in a localized conglomeratic formation known as the Colotenango Beds, located north of the fault, to the clast assemblage in the bed load of the Chixóy River, a river flowing from the south that currently crosses the Polochic fault $130 \mathrm{~km}$ east of the Colotenango Beds. They observed that the assemblages are alike, and concluded that the Colotenango Beds were deposited by the Chixóy River before the initiation of Polochic fault. They dated volcanic gravels embedded in the conglomerate to $10.3-6.5 \mathrm{My}$, an age confirmed by more recent dating of an underlying ignimbrite yielding $\sim 10$ My [Brocard et al., 2011]. They inferred that all the displacement took place after. This implies a timeaveraged slip rate of $20-13 \mathrm{~mm} / \mathrm{y}$, making the Polochic fault the main plate boundary since the Late Miocene. Burkart [1994] later used this estimate to assert that the strike-slip plate motion was entirely taken up by the Polochic fault between $10 \mathrm{My}$ and $4 \mathrm{My}$, and after $4 \mathrm{My}$ by the Motagua fault.

[9] Erdlac and Anderson [1982] challenged Burkart's [1978] interpretations and argued that the Polochic fault did not move by more than a few kilometers in the Tertiary. Brocard et al. [2011] showed that Burkart's [1983] reconstruction using drainage offset is not valid because the drainage pattern used in the reconstruction did not exist at the time of initiation of the Polochic fault: it was completely rearranged to its present form in the Latest Miocene, well after the deposition of the Colotenango Beds. In addition, the serpentinite pebbles encountered in the Colotenango Beds used as a key rock source in Burkart's [1978] reconstruction could be derived from an ophiolitic body located only within $5 \mathrm{~km}$ of the Colotenango Beds, (Figure 2). This outlier is used by Burkart [1978, 1983] as evidence for total fault offset but does not appear in Deaton and Burkart [1984] inventory of rock sources. Erdlac and Anderson [1982] also observed that, despite their location above the Polochic fault zone, the Colotenango Beds have experienced little shearing since their deposition. They also stressed that the main fault strand is located north of the conglomerates, which, if confirmed, 

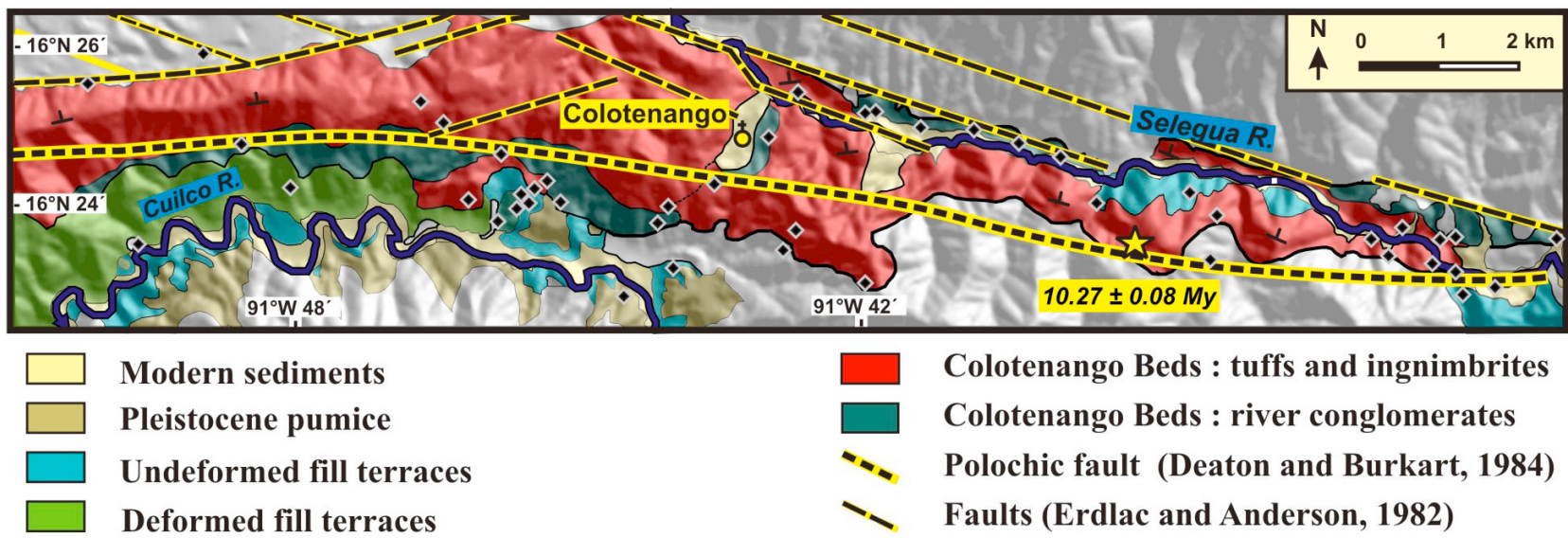

Colotenango Beds : tuffs and ingnimbrites

Colotenango Beds : river conglomerates

- Polochic fault (Deaton and Burkart, 1984)

- Faults (Erdlac and Anderson, 1982)

Figure 2. Geological sketch map of the Colotenango Beds. Solid diamonds: observation points, yellow star symbol: dated flame ignimbrite [Brocard et al., 2011]. For relative location see Figure 1.

would make the conglomerates useless for assessing tectonic displacements. Deaton and Burkart [1984] reasserted that the main shear zone is located south of the conglomerates with its northern branch being interpreted as a recent jog of the fault.

[10] Our own field observations benefited from abundant recent road cuts in the area. Accounting for new and additional evidence, we found most of Deaton and Burkart's [1984] original sections to be incorrect and the overall tectonic structure to be rather consistent with the views of Anderson et al. [1985] (Figure 2). Based on geological observations, Brocard et al. [2011] suggested that the Chixóy River might have developed its current $25-\mathrm{km}$-long tectonic deflection over the last 7.5-10 My, reducing the Polochic fault time-averaged slip velocity of $2.5-3.3 \mathrm{~mm} / \mathrm{y}$. Such values are more compatible with the present-day GPSderived velocity of $<5 \mathrm{~mm} / \mathrm{y}$ [Lyon-Caen et al., 2006], and with the interpretation of the Polochic fault as a secondary fault in the plate boundary.

\subsection{Seismic Activity of the Polochic Fault}

[11] The seismic activity along the Polochic-Motagua fault system poses a threat to some $70 \%$ of the total population of Guatemala. Both faults have generated a number of recorded and/or historically documented earthquakes [White, 1984, 1985; Plafker, 1976; White and Harlow, 1993; Ambraseys and Adams, 2001; Franco et al., 2009]. Recorded shallow earthquakes are rather uniformly distributed along the two major faults without any obvious clustering [Franco et al., 2009].

[12] The historical record of destructions related to shallow earthquakes points to two periods of intense seismic activity that alternated with periods of seismic quiescence [White, 1984] (Figure 1). The first period lasted from 1702 to $1822 \mathrm{AD}$ and terminated with two earthquakes on the Polochic fault with estimated magnitudes in excess of 7. The first of these earthquakes, with an estimated magnitude between 7.3 and 7.5, ruptured the eastern portion of the fault in 1785; the second earthquake, with an estimated magnitude of 7.5 to 7.7, ruptured the western portion of the fault in 1816 [White, 1985]. The second period of seismic activity started in 1945 and culminated in 1976 with a famous magnitude 7.5 earthquake along the Motagua fault [Plafker, 1976]. The fault ruptured over a distance of $\sim 230 \mathrm{~km}$ with co-seismic displacements along the fault amounting to $\sim 1.1 \mathrm{~m}$ on average [Plafker, 1976; Bucknam et al., 1978]. Going back in time, a major earthquake with a magnitude in excess of 7 may have occurred on the Polochic fault in 1538 AD [White, 1984]. Between 1538 and 850-890 AD archeologists have found evidence for only one paleo-earthquake along the Motagua fault when, compared to recent historical record, tens of earthquakes would be expected during this period [Kovach and Nur, 2006].

\section{Methodological Approach}

\subsection{Tectonic Analysis}

[13] We identified the active trace of the Polochic fault on black-and-white stereographic aerial photographs; using a geographical information system software (ArcGIS), this information was transmitted onto ortho-rectified panchromatic photographs with a resolution of $5 \mathrm{~m}$. The inferred course of the active fault trace, which is associated with many geomorphological features typical of strike-slip faulting, such as deflected stream channels, shutter ridges, sag ponds, and fault scarps, was verified in the field. We measured kinematic indicators in Quaternary formations to determine the recent fault kinematics (Figure 3) and, for site S1A, we successfully reconstructed the stress tensor by inverting the fault slip population based on the method of Carey [1979].

\subsection{Geoelectrical Resistivity Measurements}

[14] In order to explore how the fault affects Quaternary deposits at depth, we set up a number of geoelectric profiles. The basic principle behind geoelectrical resistivity measurements is to inject an electrical current into the subsurface through a pair of galvanically coupled electrodes and to measure the resulting difference in voltage between another pair of electrodes. Using Ohm's law, this allows the apparent electrical resistivity of the probed subsurface region to be measured. Geoelectrical techniques have progressed from conventional mapping and vertical sounding to the tomographic imaging of heterogeneous distributions of electrical resistivity in the subsurface [e.g., Kearey et al., 2002]. This technique, which is now commonly referred to as electrical resistivity tomography or ERT, is remarkably robust and reliable for providing realistic, albeit strongly smoothed, 


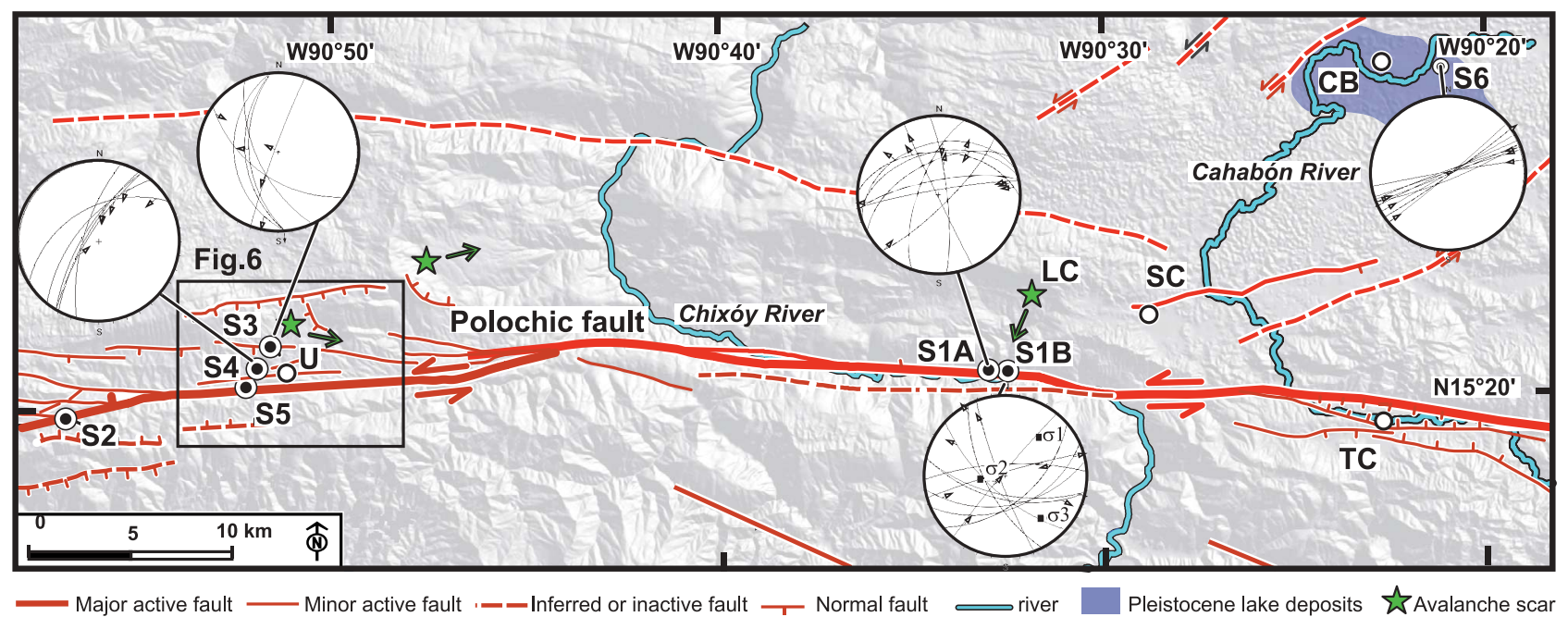

Figure 3. Trace of major active faults and Quaternary fault kinematics data in Chixoý and Uspantán regions. Locations: S1-S6: studied sites, CB: Cobán, LC: Los Chorros rock avalanche, SC: San Cristóbal Verapaz, TC: Tactic, U: Uspantán. For relative location see Figure 1. Fault populations are shown in lower hemisphere stereonets.

images of the spatial electrical resistivity distribution [e.g., Binley and Kemna, 2005]. Recently, ERT has proven to be valuable for locating and characterizing faults [e.g., Diaferia et al., 2006; Caputo et al., 2007; Suski et al., 2010], for identifying suitable sites for invasive paleo-seismological investigations such as trenching [e.g., Wise et al., 2003; Nguyen et al., 2007], and for characterizing surficial regions that are affected by fault activity [e.g., Suzuki et al., 2000; Caputo et al., 2003; Colella et al., 2004; Rizzo et al., 2004; Suski et al., 2010].

[15] In February 2008, we used ERT to image the subsurface structure of the Polochic fault zone at site S1A near Agua Blanca (Figure 3), south of the city of San Cristobál Verapaz, as well as at site S3 near Cotoxac, north of San Miguel Uspantán (Figure 3). The data were acquired using a Syscal multichannel resistivity system and a WennerSchlumberger array consisting of 48 steel electrodes spaced at $5 \mathrm{~m}$ intervals, which provides a maximum exploration depth of $\sim 30-40 \mathrm{~m}$. The Wenner-Schlumberger electrode arrangement exhibits favorable signal-to-noise ratio and offers a reasonably high sensitivity in both the horizontal and vertical directions [Loke, 1999]. The measured apparent electrical resistivity data were tomographically inverted into "true" electrical resistivity distributions using a smoothnessconstrained least squares algorithm in conjunction with a quasi-Newtonian optimization technique [Loke and Barker, 1996]. The starting models are constant electrical resistivity distributions equivalent to the average apparent electrical resistivity values of the corresponding pseudo-sections. The tomographic inversion method iteratively adjusts the $2 \mathrm{D}$ electrical resistivity distribution to reduce the difference between the calculated and measured apparent electrical resistivity. The root-mean square (RMS) error provides a measure of this difference and a first-order estimate for the reliability of the final results. In the case of the profiles presented here, convergence was generally achieved after 3 to 5 iterations with final RMS errors ranging from 2 to $6 \%$. Both the rapid convergence and low RMS errors indicate that the tomographic images used in this study can be regarded as robust and reliable.

\subsection{Cosmogenic ${ }^{36} \mathrm{Cl}$ Surface Exposure Dating}

[16] We selected site S1B (Figure 3) to quantify the slip rate of the Polochic fault. This site is ideal for this purpose because: (i) it displays a single active strike-slip fault trace corresponding to the Polochic fault; (ii) the fault offsets a well preserved alluvial fan surface; and (iii) this fan has been fed by a rapidly eroding catchment, which minimizes inheritance issues for dating the fan surface. We measured in situproduced cosmogenic ${ }^{36} \mathrm{Cl}$ in carbonate boulders that are scattered over the surface of the fan in order to obtain the exposure age (Figure 5). This age, which is associated with the tectonic lateral offset, allows us to calculate the horizontal slip rate of the fault.

[17] The ${ }^{36} \mathrm{Cl}$ isotope is produced by four reaction mechanisms near the Earth's surface: (i) cosmogenic spallation of $\mathrm{K}, \mathrm{Ca}, \mathrm{Ti}$, and $\mathrm{Fe}$; (ii) slow capture of cosmic muons by $\mathrm{K}$ and $\mathrm{Ca}$; (iii) low energy, thermal and epithermal, capture of cosmogenic secondary neutrons by ${ }^{35} \mathrm{Cl}$; and (iv) capture of low energy radiogenic neutrons produced by the decay of U and Th by Cl [Stone et al., 1996, 1998; Gosse and Phillips, 2001; Schimmelpfennig et al., 2009]. We measure the ${ }^{36} \mathrm{Cl}$ produced in the lattice of calcite of known chemical composition, in order to convert correctly the measured ${ }^{36} \mathrm{Cl}$ concentrations into ages.

[18] The carbonate major elemental composition was measured by inductively coupled plasma optical emission spectrometry (ICP-OES) at the Centre Européen de Recherche En Géosciences de l'Environnement (CEREGE) in Aix-enProvence, France (Table 1a). For $\mathrm{Cl}$ extraction, the samples were first ground and dissolved followed by precipitation as silver chloride according to the protocol of Stone et al. [1996]. ${ }^{36} \mathrm{Cl}$ and other chloride isotopes were measured by isotope dilution accelerator mass spectrometry (AMS) at the Lawrence Livermore National Laboratory, California, USA. The chemical blanks concentrations are two orders of 
magnitude lower than those of the samples and replicate concentrations are less than 5\% dissimilar. We use the formulas from Stone et al. [1998], Gosse and Phillips [2001] and other references therein compiled by Schimmelpfennig et al. [2009] to calculate in situ ${ }^{36} \mathrm{Cl}$ production and exposure ages. The calculation takes into account the four in situ ${ }^{36} \mathrm{Cl}$ production mechanisms mentioned above and the latitude and elevation of the sample locations as well as the topographic shielding for the computation of the scaling factors with regard to the cosmogenic ${ }^{36} \mathrm{Cl}$ production rate. Calculations also incorporate corrections owing to surface geometry, sample thickness, and chemical composition.

[19] The in situ ${ }^{36} \mathrm{Cl}$ production rate can be described as decreasing exponentially with depth beyond a maximum efficiency peak at a depth of $20-50 \mathrm{~cm}$ induced by thermal and epithermal neutrons capture to ${ }^{35} \mathrm{Cl}$ [Gosse and Phillips, 2001]. Time-integrated changes in depth due to surface erosion will affect the history of ${ }^{36} \mathrm{Cl}$ accumulation and the computed apparent exposure age. If erosion removed a layer of rock thinner that the depth of maximum ${ }^{36} \mathrm{Cl}$ accumulation but is omitted in the calculation, the apparent exposure age is overestimated. Conversely, if erosion proceeded deeper to a zone of lesser accumulation, the apparent exposure age is underestimated. In the following section, we estimate the minimum and maximum denudation rates that can be expected for our samples in order to obtain a reasonable range of possible ages for the formation of the fan surface.

[20] For our analyses, we chose large boulders with diameters of at least $1 \mathrm{~m}$ protruding from the fan surface to ensure that the blocks were not initially buried below the original depositional surface, but clearly inset in the fan surface in order to avoid post-emplacement toppling (Figure 5d). Boulders exhibiting obvious signs of spalling were avoided. All the blocks were affected by surface dissolution (Figure 5f) as shown by dissolution pits on the top of the boulders, which indicates that the blocks have remained in an upright position. Samples were collected within 1-7 cm of the boulder surface. The fan feeding catchment is a steep and short valley that is subjected to repeated rock avalanches, such as the one in February 2009 at Los Chorros, which mobilized some $5 \times 10^{6} \mathrm{~m}^{3}$ of carbonate debris. Deposits from this and older events show that rock avalanche materials are rapidly dissected and dispersed downstream. The studied fan consists of several fan lobes that were rapidly constructed after former avalanche events. This scenario of sudden, deep unearthing is ideal for preventing significant inheritance, because it minimizes the possibility that significant amounts of in situ-produced cosmogenic ${ }^{36} \mathrm{Cl}$ have accumulated during the final exhumation of the sample across these upper few meters of the subsurface, where cosmogenic production occurs.

\section{Results}

\subsection{Segmentation of the Polochic Fault}

[21] Fault segment length influences the length and style of fault rupture during an earthquake, the magnitude of which largely depends on the fault area affected by the rupture [Wells and Coppersmith, 1994]. The Polochic fault is divided into three parts of similar length $(\sim 170 \mathrm{~km})$, which we named Izabal, Chixoý, and Cuilco according to the lake and rivers flanking these fault parts (Figure 1). The eastern Izabal strand strikes $\mathrm{N} 70^{\circ}$, from the western end of the lake Izabal basin to an offshore connection with the Motagua fault. This strand delineates an overall releasing bend that hosts the Izabal lake basin and is subdivided into three $50-90 \mathrm{~km}$ long major segments. Length-magnitude scaling relationships [Wells and Coppersmith, 1994] suggest that the individual rupture of one of these segments can generate an earthquake of magnitude 7.0-7.4 with a maximum co-seismic displacement of $1.8-3.7 \mathrm{~m}$.

[22] The Chixóy part of the Polochic fault, from the lake Izabal basin to Huehuetenango is made of four $30-50 \mathrm{~km}$ long major segments linked by step-overs. Numerous minor faults splay off these major segments. Each segment can generate earthquakes of magnitude 6.8-7.1 and maximum coseismic displacements of $0.9-2.1 \mathrm{~m}$.

[23] The Cuilco part of the Polochic fault, from Huehuetenango to the Pacific coast forms a restraining bend with abundant splays. Some northwest trending faults splay toward the Chiapas depression or connect with the coastal Tonala fault (Figure 1). Northeast-striking releasing normal faults have created a depressed zone south of Huehuetenango. The Cuilco part of the Polochic fault is comprised of six major segments of decreasing lengths from 41 to $10 \mathrm{~km}$ toward the west. The associated seismic hazard therefore decreases accordingly with the expected earthquake magnitudes that diminish from 7.0 to 6.3 . The spatial extent of destructions attributed to historical earthquakes [White, 1984] indicates that the large earthquakes have ruptured over half of the total length of the fault system and thus simultaneously involved multiple segments.

[24] We focused our analysis on the Chixóy part of the Polochic fault between Uspantán and Tactic, where active sediment deposition along the fault trace records recent deformation (Figures 1 and 3). We consider five sites that clearly exhibit Quaternary faulting. Sites 1A and 5 expose the fault structure. Site $1 \mathrm{~B}$ is used for ${ }^{36} \mathrm{Cl}$ dating to quantify the Holocene horizontal slip rate of the Polochic fault. Sites 1A, $2,3,4$, and 5 show vertical displacements affecting geological and geomorphological markers, such as alluvial fans, Quaternary volcanic formations, avalanche deposits, and alluvial terraces; at site $1 \mathrm{~A}$ electrical resistivity tomography imaged the subsurface structure of a deflected stream. Site 5 was radiocarbon dated, thus providing vertical displacement rates and Late Pleistocene paleo-seismological constraints. Site 6 , located $15 \mathrm{~km}$ north of the Polochic fault, displays strike-slip faulting in Pleistocene lake deposits of the Jolomná formation (Figure 3). This indicates that the Polochic fault is surrounded by a broad corridor of diffuse left-lateral shearing activating subparallel faults. The deposits are sliced by northeast trending left-lateral strike-slip faults that we interpret as synthetic Riedel-type faults within an east-west trending strike-slip shear zone extending from the Polochic fault up to the Ixcán fault to the north [GuzmánSpeziale, 2010] and up to the northern faults of the Caiman Trough, which show offshore evidence of Quaternary activity in southern Belize [Lara, 1993].

\subsection{Slip Rate in the Chixóy River Valley}

\subsubsection{Fault Zone Structure and Offsets}

[25] The Chixóy River flows for $25 \mathrm{~km}$ within a deep valley along the Polochic fault (Figure 3 ). In this valley, the fault offsets northern tributaries of the Chixóy River and their 


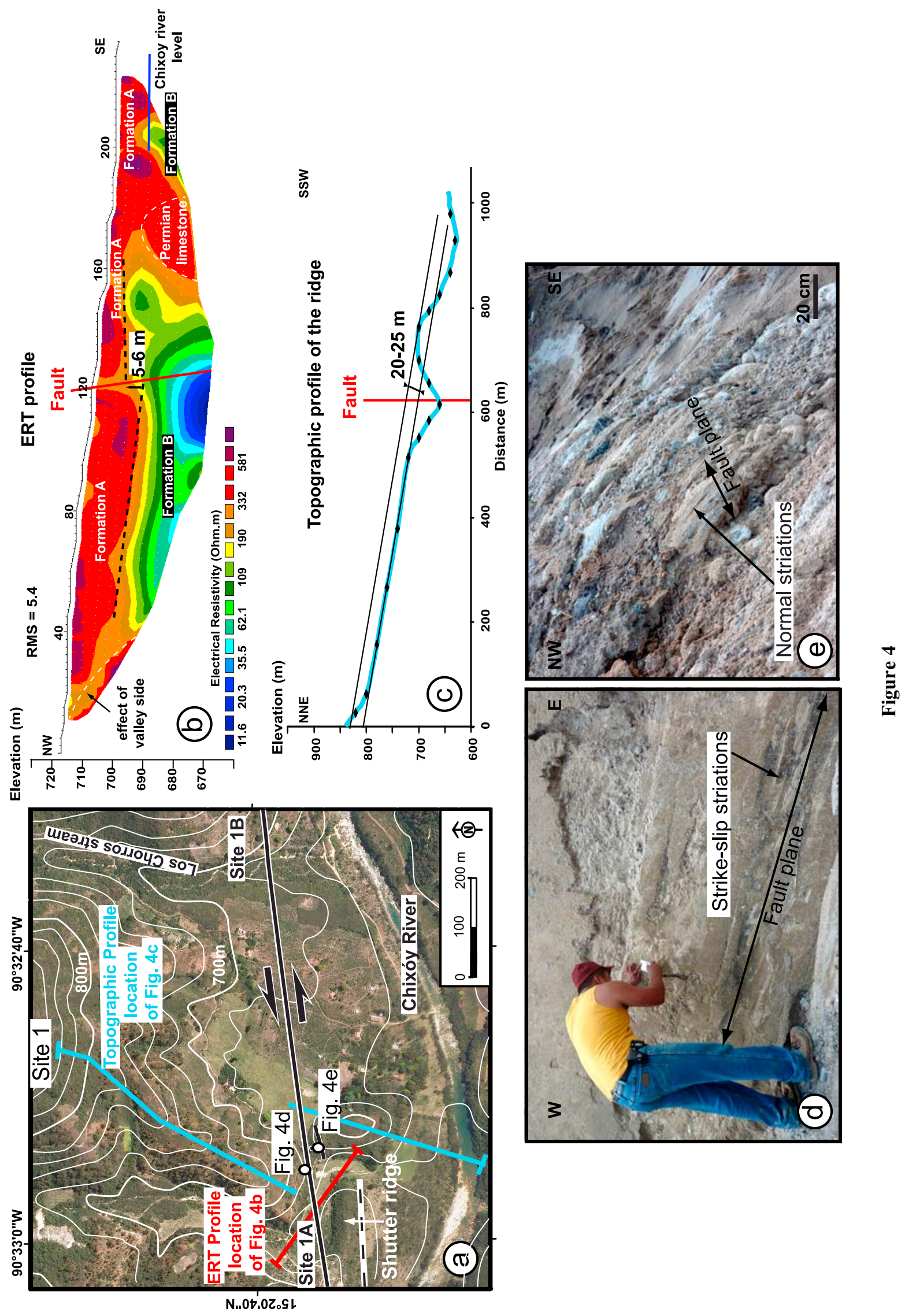


alluvial fans. The fan in Agua Blanca (site 1B, Figures 4 and 5 ) is unusually large (Figure $4 \mathrm{a}$ ) and is younger than the 84 ky old Los Chocoyos pumice ash flow deposits [Drexler et al., 1980; Rose et al., 1987] into which it develops (Figure 5a). The fan was able to grow to such an unusual size by the repeated accumulation of debris flows that occurred during the Holocene. The debris flows originated by rapid reworking of rock avalanche deposits soon after their deposition upstream in the feeder catchment. The most recent collapse occurred in February 2009 and generated a $5 \times$ $10^{6} \mathrm{~m}^{3}$ rock avalanche. The composite morphology of the Agua Blanca fan surface together with several levels of fill terraces along Los Chorros stream point to a few sudden large increments of fan growth that followed each avalanche event.

[26] Before the February 2009 avalanche, the feeder stream was incised $6 \mathrm{~m}$ below the fan surface and exhibited a leftlateral tectonic deflection (Figure 5a). Other northern tributaries of the Chixóy River show similar, larger leftlateral deflections, such as the one located immediately west of the fan (site 1A, Figures 3 and 5a). There, a smaller stream exhibits a $148 \pm 38$-m-long deflection of its course before joining the Chixóy River. This intermittent stream, incised several tens of meters into the surrounding hills, is graded to the Chixoý River and is actively depositing sediment along its course.

[27] To better understand the structure of the Polochic fault at site 1A, we used ERT to image the subsurface along the deflected stream. The corresponding tomographic image (Figure 4b) displays a 5-15-m-thick highly resistive surficial layer (300-700 $\mathrm{Ohm} \cdot \mathrm{m})$ overlying more conductive material $(10-200 \mathrm{Ohm} \cdot \mathrm{m})$. A $1.5 \mathrm{~m}$ deep trench excavated in 2009 in that surficial layer (formation A) showed that is composed of stacked, $10 \mathrm{~cm}$ thick inceptisols alternating with $50 \mathrm{~cm}$ thick channel belts filled with limestone and dolomite gravel. The high resistivity values observed for this surficial region imply that these alluvial deposits were dry at the time of measurement. The top of the underlying formation B slopes $\sim 7^{\circ}$ toward the Chixóy River and could represent the top of the water table. However, before grading into the river, this surface abruptly shifts vertically upward, which means that the induced slope stands in the way of groundwater flow toward the Chixóy River. Alternatively, the top of formation $\mathrm{B}$ is a buried depositional transition between formation $\mathrm{A}$ and an older, more conductive formation B.

[28] The top of formation B exhibits a localized 5-6-mhigh elevation rise toward the Chixoý River (Figure 4b). We propose that a fault is located there and disrupts the subsurface. If formation $\mathrm{B}$ is lithologically different from formation $\mathrm{A}$, then the southern rise of formation $\mathrm{B}$ indicates that this part of the profile has been tectonically uplifted. This discontinuity was not observed in the trench excavated into formation $\mathrm{A}$, thus suggesting that the corresponding rupture occurred before the deposition of the upper $1.5 \mathrm{~m}$ of formation A. Elevation rise of the southern side is also noticeable in the topography of the ridge separating the deflected stream from the Agua Blanca fan. The crest of this ridge is everywhere composed of 84-ky-old Los Chocoyos pumice [Drexler et al., 1980; Rose et al., 1987]. The ridge is leftlaterally offset by the fault, and a longitudinal topographic profile of the ridge crest (Figure 4c) shows that its southern part is higher, and the height difference suggests that it has been uplifted by as much as $20-25 \mathrm{~m}$ with respect to its northern part.

[29] The walls of a large sluiceway that was excavated in 2010 provide a section through the ridge. North of the fault, the ridge is composed of pumice resting unconformably on alluvium tilted to the north. The alluvium consists of silt and gravel containing serpentinite pebbles that point to the Chixoý River as the sediment source (Figure 5a). South of the fault, the ridge is composed of gravel of local origin (limestone and dolomite of formation A) that were deposited by the deflected tributary and overlain by pumice. The local stream deposits are uplifted at least $12-15 \mathrm{~m}$ above the modern floodplain of the same stream, and are in contact with the pumice of the northern side along a N70-striking, north-dipping normal fault (Figure 4e).

[30] Left-lateral shearing of the ridge is evidenced by a $\mathrm{N} 90^{\circ}$-striking fault plane located $30 \mathrm{~m}$ further north that affects both the pumice and the underlying Chixóy River deposits (Figure 4d). The fault dips to the south and exhibits a succession of striations that indicate a progression from pure left-lateral strike slip (pitch $\left.9^{\circ} \mathrm{E}\right)$ to oblique $\left(16^{\circ} \mathrm{E}\right)$ to dominantly normal displacement. The ridge on other side of deflected valley to the west is also composed of pumice, but at its southern termination, after passing the fault, the pumice rests on an E-W striking fault-parallel slice made of limestone of the Permian Chochal formation in vertical beds striking oblique relative to the East-trending Polochic fault at $\mathrm{N} 130^{\circ}$ (Figure 5a). The eastern termination of this slice makes the shutter-ridge that deflects the stream at site $1 \mathrm{~A}$. The sinistral motion along the fault has displaced this slice and currently partially blocks the stream (Figure 5a). The shutter-ridge lines up with uplifted local stream deposits east of the deflection, indicating that the shutter-ridge results from both lateral and upward displacements (Figure 4a). These observations in and around the valley indicate that the local trans-tensional regime is variously, and sometimes strongly, partitioned in time and space over several fault strands.

[31] At site 1A fault motion has produced a lateral stream offset of $148 \pm 38 \mathrm{~m}$ with the uncertainty accounting for the width of the stream (Figure $5 \mathrm{a}$ ). To the east, before its complete burial under the 2009 debris flows, the eastern

\footnotetext{
Figure 4. Geological and geophysical observations at site 1A (Agua Blanca). (a) 0.5-m-resolution aerial photograph of site 1 with superimposed $20 \mathrm{~m}$ contours (thin white lines) showing the Polochic fault trace and the location of the ERT (red line) and the topographic profile (blue line). The dotted black line corresponds to a minor fault. (b) ERT profile located on Figure 4a showing the measurement of the vertical offset of the formation B top surface. The black dashed line delineates the inferred boundary between formations A and B. The white dashed line indicates the effect of valley side. Red line shows the Polochic fault trace (Figure 4a). (c) Topographic profile produced from the 20-m-interval contours of the 1:50,000 topographic map and vertical offset of the topographic surface through the Polochic fault trace (Figure 4a). (d) View of a strike-slip fault plane affecting Los Chocoyos pumice (Figure 4a). (e) View of a normal fault plane affecting old alluvial Chixoy river deposits (Figure 4a).
} 

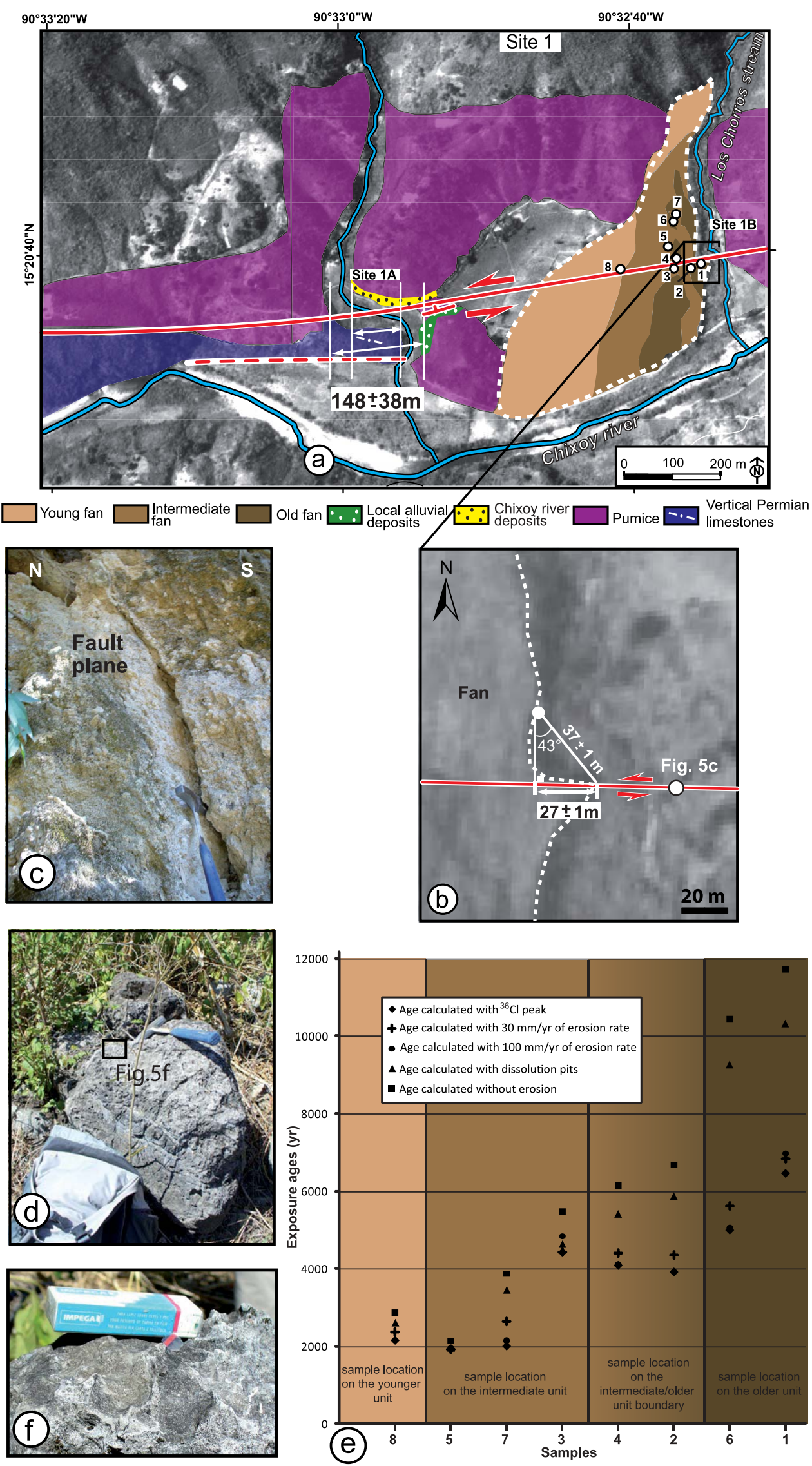

Figure 5 
Table 1a. Elemental Composition (\%) of Elements Used of the Dating Calculation

\begin{tabular}{ccccccccccccc}
\hline Site & $\mathrm{Al}_{2} \mathrm{O}_{3}$ & $\mathrm{CaO}$ & $\mathrm{Fe}_{2} \mathrm{O}_{3}$ & $\mathrm{~K}_{2} \mathrm{O}$ & $\mathrm{MgO}$ & $\mathrm{MnO}$ & $\mathrm{Na}_{2} \mathrm{O}$ & $\mathrm{P}_{2} \mathrm{O}_{5}$ & $\mathrm{SiO}_{2}$ & $\mathrm{TiO}_{2}$ & $\mathrm{Th}$ & $\mathrm{U}$ \\
\hline 1 & 0,04 & 34,06 & 0,05 & 0,00 & 19,07 & 0,01 & 0,00 & 0,02 & 0,00 & 0,03 & $<3$ & $<2$ \\
2 & 0,05 & 35,29 & 0,05 & 0,00 & 17,96 & 0,02 & 0,00 & 0,01 & 0,00 & 0,03 & $<3$ & $<2$ \\
3 & 0,21 & 48,73 & 0,10 & 0,00 & 6,00 & 0,03 & 0,03 & 0,02 & 1,21 & 0,02 & $<3$ & $<2$ \\
4 & 0,02 & 32,54 & 0,03 & 0,00 & 21,35 & 0,04 & 0,00 & 0,01 & 0,00 & 0,02 & $<3$ & $<2$ \\
5 & 0,07 & 46,18 & 0,03 & 0,00 & 8,30 & 0,05 & 0,02 & 0,02 & 0,34 & 0,03 & $<3$ & $<2$ \\
6 & 0,07 & 34,04 & 0,04 & 0,00 & 19,62 & 0,06 & 0,00 & 0,02 & 0,00 & 0,01 & $<3$ & $<2$ \\
7 & 0,09 & 38,37 & 0,06 & 0,00 & 14,77 & 0,07 & 0,01 & 0,01 & 0,10 & 0,03 & $<3$ & $<2$ \\
8 & 0,05 & 34,31 & 0,06 & 0,00 & 19,52 & 0,08 & 0,00 & 0,02 & 0,00 & 0,01 & $<3$ & $<2$ \\
\hline
\end{tabular}

boundary of the alluvial fan exhibits a deflection of $27 \pm 1 \mathrm{~m}$ according to laser range finder measurements (Figure 5b). The active fault trace of the Polochic fault associated with this deflection is recognizable in the field by striations on fan pebbles and a tectonic breccia with a clear fault plane on the opposite bank of Los Chorros stream (Figure 5c). Inversion of fault slip data indicates a left-lateral, strike-slip regime associated with a northeast trending principal axis of compression $\sigma_{1}$ (Figure 3).

\subsubsection{Age of Displaced Features}

[32] The Los Chocoyos ash flows filled the Chixóy River valley with pumice up to $\sim 100 \mathrm{~m}$ above its modern floor $\sim 84$ ky ago The pumice completely buried the limestone making shutter-ridge at site $1 \mathrm{~A}$, together with the surrounding alluvial deposits (Figure 5a). Thus the pumice buried any topographic obstruction between the Chixoý River and the streams at site 1 . The stream at site $1 \mathrm{~A}$ was free to flow over the surface of the pumice into the Chixóy River. When the stream started to incise, it superimposed its course onto the formations underlying the pumice, thus establishing and anchoring its course across the tectonic slice. The tectonic deflection of the stream postdates this superposition and is thus younger than $\sim 84 \mathrm{ky}$.

[33] The Agua Blanca fan surface at site $1 \mathrm{~A}$ is dotted with meter-size boulders. In detail, the fan surface is composed of imbricated units, the surfaces of which are slightly inset into one another (Figure 5a). Each unit is believed to have been emplaced rapidly, probably within a few years, by the accumulation of debris flows following a rock avalanche further upstream, as it has been the case following a rock avalanche in 2009. We classified these surfaces based on their relative topographic position, degree of weathering, and subsurface soil development. According to these criteria, we identified three main surfaces that we refer to as the older, intermediate, and younger fan-forming surfaces, the ages of which were determined using cosmogenic ${ }^{36} \mathrm{Cl}$ exposure dating (Table 1b). To this end, we sampled 8 large carbonate boulders with diameters in excess of $1 \mathrm{~m}$ (Figure $5 \mathrm{~d}$ ).
[34] To define the range of possible exposure ages, we considered various rates of carbonate weathering. If one assumes no erosion since boulder deposition, exposure ages range from $1.9 \pm 0.2 \mathrm{ky}$ to $10.7 \pm 1.0 \mathrm{ky}$ (Table $1 \mathrm{c}$, first column). These apparent ages are found to be overall in correct relative chronologic order, with all the oldest boulders found on the oldest surface and the younger ones on the youngest surface, still with considerable internal variability within each surface (Figures 5a and 5e). One exception is sample GUA-5, which bears the lowest exposure age despite being located in the intermediate surface.

[35] The boulder surfaces have actually subjected to dissolution, as evidenced by dissolution pits on the boulder upper surfaces. The dissolution pits result from a combination of weakly acidic rainfall and from the metabolic activity of endolithic cyanobacteria [Danin et al., 1983]. Dissolution of carbonate is closely linked to annual precipitation [Reddy, 1989]. Because the dissolution process is cumulative [Lipfert, 1989], variations in dissolution rates resulting from climate oscillations on timescales shorter than a millennium will average out over larger timescale, so that the rates measured here can be regarded as nearly constant.

[36] We measured the depth of several surface pits on each boulder to obtain an average depth (Figure $5 \mathrm{f}$ and Table 1c) and to correct the apparent exposure ages accordingly. This depth is the minimum amount of erosion that the surface has experienced, because the rock area between adjoining pits is not necessarily the initial surface of the boulder before dissolution started. Denudation rates were then calculated using the method of Schimmelpfennig et al. [2009] by iteratively searching for the most likely denudation rate and exposure age combination that fits the measured pairs of ${ }^{36} \mathrm{Cl}$ concentration and minimum amount of erosion (Table 1c). Exposure ages obtained with this approach range between 1.9 and $10.3 \mathrm{ky}$ (Table 1c, fourth column), slightly younger than for the apparent ages from the no-erosion scenario; and the best fit minimum erosion rates range from 0.6 to $3.8 \mathrm{~mm} /$ ky. These minimum erosion rates are comparable to the

\footnotetext{
Figure 5. Geological observations and ${ }^{36} \mathrm{Cl}$ sampling at site $1 \mathrm{~B}$ (Agua Blanca fan). (a) Aerial photograph indicating the geological units of the alluvial fan and its environment and the lateral offset of the Agua Blanca stream valley. Numbers refer to the collected geochronological samples. White lines correspond to the minimum and the maximum extension of the horizontal stream offsets taking into account the width of the valley. (b) Detail of the eastern fan boundary lateral offset and its measurement. (c) View of the Polochic fault plane in pumice in the prolongation of the fan lateral offset (Figure 5b). (d) View of the carbonate boulder (number 2) sampled for the ${ }^{36} \mathrm{Cl}$ cosmogenic dating on the alluvial fan surface. (e) Exposure ages of samples calculated with various methods and sample location according to the alluvial fan units. (f) View of dissolution pits on the boulder top surface.
} 
Table 1b. Sample Characteristics ${ }^{\mathrm{a}}$

\begin{tabular}{|c|c|c|c|c|c|c|c|}
\hline Site & $\begin{array}{l}\text { Latitude } \\
\left({ }^{\circ} \mathrm{N}\right)\end{array}$ & $\begin{array}{l}\text { Altitude } \\
\text { (m) }\end{array}$ & $\begin{array}{l}\text { Thickness } \\
(\mathrm{cm})\end{array}$ & $\begin{array}{c}\mathrm{Ca} /(\mathrm{g} \text { rock }) \\
(\%)\end{array}$ & $\begin{array}{l}\text { Chlorine } \\
\text { (ppm) }\end{array}$ & $\begin{array}{c}36 \mathrm{Cl} \\
{\left[\text { atoms }(\mathrm{g} \text { rock })^{-1}\right]}\end{array}$ & $\begin{array}{c}{ }^{36} \mathrm{Cl} \text { Production Rate } \\
\text { [atoms }\left(\mathrm{g} \text { rock) }{ }^{-1} \mathrm{yr}^{-1} \text { ] }\right. \\
\text { for Uneroded Surface }\end{array}$ \\
\hline 1 & 1697887 & 696 & 6 & 24,6 & 306 & $290529 \pm 13891$ & 27,3 \\
\hline 2 & 1697878 & 699 & 5 & 26,6 & 288 & $217027 \pm 8643$ & 27,2 \\
\hline 3 & 1697877 & 706 & 7 & 37,9 & 90 & $121713 \pm 18061$ & 25 \\
\hline 4 & 1697894 & 711 & 6 & 22,7 & 149 & $120182 \pm 4438$ & 21 \\
\hline 5 & 1697922 & 716 & 7 & 24,7 & 51 & $42999 \pm 1670$ & 22 \\
\hline 6 & 1697973 & 726 & 5 & 23,1 & 535 & $378965 \pm 12324$ & 39,8 \\
\hline 7 & 1697988 & 730 & 6 & 27,4 & 492 & $145645 \pm 7390$ & 38,7 \\
\hline 8 & 1697876 & 720 & 4 & 26,4 & 102 & $51850 \pm 2258$ & 19,7 \\
\hline
\end{tabular}

"Here "g rock" corresponds to "per gram of rock."

erosion rate of $2.4 \mathrm{~mm} / \mathrm{ky}$ measured using the dissolution pits of carbonate boulders on Holocene debris fans of the Grand Canyon of Colorado, in a semi-arid environment [Hereford et al., 1996]. However, these erosion rates are less than the bulk $30 \mathrm{~mm} / \mathrm{ky}$ dissolution rate obtained by Corbel [1959] from the measurement of solute exports from the Guatemalan carbonate highlands. The average number of rainy days per year in the Chixóy River valley is $\sim 125$, the average temperature lies between 20 and $25^{\circ} \mathrm{C}$, and the annual rainfall fluctuates between 1000 and $1500 \mathrm{~mm} / \mathrm{y}$ [INSIVUMEH, Guatemala, Puente Chixóy weather station]. The long-term sub-aerial denudation of bare carbonate surfaces in similar subtropical regions of Japan is estimated to be $20-60 \mathrm{~mm} / \mathrm{ky}$, using the same ${ }^{36} \mathrm{Cl}$ exposure dating method [Matsushi et al., 2010], which is comparable to rates of $18-29 \mathrm{~mm} / \mathrm{ky}$ and from moist-temperate regions of Eastern Australia [Stone et al., 1994] and of $32 \mathrm{~mm} / \mathrm{ky}$ in tropical Irian Jaya, Indonesia [Peterson, 1982]. Based on these considerations, we adopted the regional dissolution rate of Corbel [1959] to calculate exposure ages. The resulting ages range from 1.9 to $6.8 \mathrm{ky}$ (Table 1c, seventh column).

[37] Compilations of hundreds of studies worldwide [Priesnitz, 1974; Smith and Atkinson, 1976] suggest that for the climate considered in this study, carbonate dissolution rate is lower than $100 \mathrm{~mm} / \mathrm{y}$, which we use as the maximum possible dissolution rate in our case study. This leads to exposure ages ranging from 1.9 to $7.0 \mathrm{ky}$ (Table $1 \mathrm{c}$, ninth column). Because ${ }^{36} \mathrm{Cl}$ production peaks a few centimeters below the rock surface, dissolution increases apparent exposure ages at low dissolution rate, and decreases apparent exposure ages at higher dissolution rate. This value is agedependent and thus differs from boulder to boulder. The erosion rate at which this shift occurs therefore varies from 36 to $191 \mathrm{~mm} / \mathrm{y}$ (Table 1c, twelfth column), with corresponding corrected ages of 1.9 to $6.4 \mathrm{ky}$ (Table 1c, eleventh column). These rates that set the youngest ages are 2 to 6 times higher than the ones calculated using the regional average [Corbel, 1959], these values of dissolution rates are plausible. In the following, we therefore assess the uncertainty on the fault slip rate by using the minimum age provided by the ${ }^{36} \mathrm{Cl}$ peak method, and the maximum age provided by the analysis of dissolution pits as bounding values and we derive from these values and the fan offset a minimum and maximum fault slip rate, respectively.

\subsubsection{Quaternary Strike-Slip Rates}

[38] The $148 \pm 38 \mathrm{~m}$ lateral offset of the stream incised into the $84 \mathrm{ky}$-old pumice at site $1 \mathrm{~A}$ yields a minimum leftlateral slip rate of $\sim 1.3 \mathrm{~mm} / \mathrm{y}$. Applying the horizontal slip rate to the minimum lateral offset of $26 \mathrm{~m}$ of the Agua Blanca alluvial fan provides a maximum age for the fan of $20 \mathrm{ky}$. To account for the measured ${ }^{36} \mathrm{Cl}$ concentrations using this age, the dissolution rate would have to reach improbable values of 190-790 mm/ky (Table 1c, last column). This minimum horizontal slip rate of $\sim 1.3 \mathrm{~mm} / \mathrm{y}$ is therefore probably significantly below the actual slip rate. At site $1 \mathrm{~B}$, offset of the Agua Blanca fan affects the oldest surface of the alluvial fan. The minimum and maximum exposure ages determined using the ${ }^{36} \mathrm{Cl}$ method indicate that the older unit was emplaced sometime between 3.9 and $10.3 \mathrm{ky}$ (Table 1c; samples 1, 2, 4, 6). The lateral fan offset of $27 \pm 1 \mathrm{~m}$ yields a left-lateral slip rate of $4.8 \pm 2.3 \mathrm{~mm} / \mathrm{y}$. The minimum slip rate value of $2.5 \mathrm{~mm} / \mathrm{y}$ obtained from more reasonable dissolution rates in relation with the climatic context of the study zone is more consistent than the value derived from the offset stream.

\subsection{Vertical Displacements Around the Polochic Fault Near Uspantán}

[39] The 6-km-wide Uspantán valley hosts a perfectly east-west trending, 25-km-long fault damage zone. The topography and abundance of recent deposits is particularly suited for the detection of secondary active faults and for understanding the width and deformation style of the damage zone (sites 2-5, Figure 3). The main central segment of the Polochic fault coincides with the valley axis, while secondary segments are widely distributed over the flanks of the valley (Figure 3). These faults determine topographic steps that increase in height with increasing distance from the main central segment. During a period of strong uplift in the Late Miocene, the fault zone was a positive flower structure with thrusts extending as far as $8 \mathrm{~km}$ to the south of the main strand [Authemayou et al., 2011]. Currently this outer positive flower structure is obliterated in its center by a younger negative flower structure. Within $2 \mathrm{~km}$ of the main fault to the south, a Late Miocene ignimbrite is down thrown by several hundreds of meters across large normal fault scarps (Figure 6). North of the Polochic fault, these normal faults are mirrored by another set of east-west trending, recent and active normal faults, some of which are reactivated faults of Eocene age or older. It is unclear whether all normal faults merge at depth with the main strand or accommodate a widespread gravitational collapse of the northern side of the valley. In the meantime, the axis of the valley itself is lined with several tectonic slices where transpressional deformation prevails. In the following, we analyze the origin and 


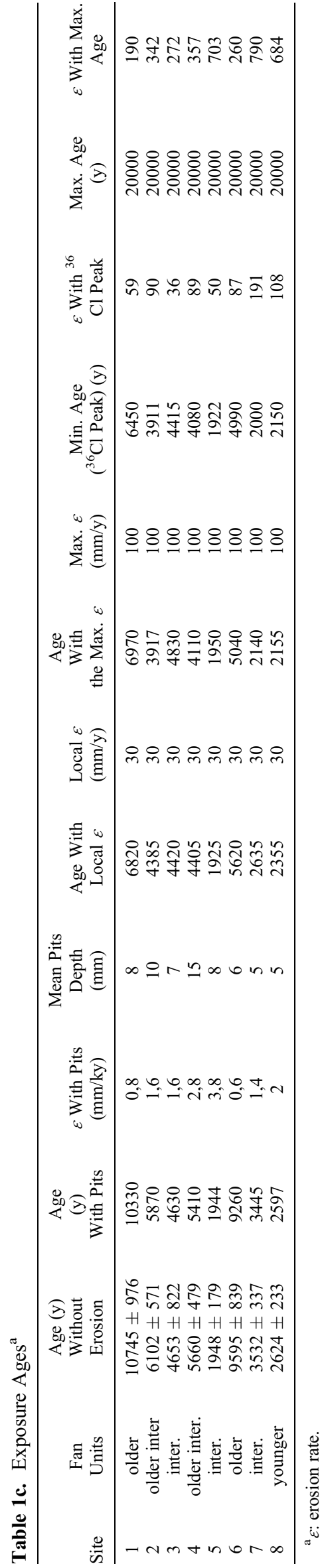

patterns of recent vertical displacements generated across this structure.

\subsubsection{Extension-Related Vertical Displacements}

[40] Normal faulting occurs on faults at the western termination of the main strand and on the outermost faults of the flower structure. Site 2 is located at the western termination of the main central strand (Figure 3). There, before turning back to an E-W strike further west along this strand, the active trace briefly turns toward the southwest and prefiguring interferences with an array of northeast trending normal faults that develop further west, south of the Polochic fault near the western termination of its central Chixoý part (Figure 1). At site 2, two generations of imbricate alluvial fans are disrupted by a fault scarp (Figure 7). Laser rangefinder measurements indicate that the fault scarp is $10 \mathrm{~m}$ high across the older fans and $2 \mathrm{~m}$ high across the younger fans. These normal fault scarps suggest that the change in strike of the fault creates a small releasing bend within an otherwise east-west trending pure left-lateral shear regime. Mapping of the deformation zone along the Uspantán valley, however, reveals that other east-west trending faults accommodate vertical displacements.

[41] Although parallel to the axial fault, the outer faults of the negative flower structure generally display dip-slip normal faulting. Site 4 is a faulted travertine fan on the northern flank of the valley (Figures 6 and 8). The river that built this fan flows over Cretaceous limestone, dolomite, and gypsum, and its water has a high sulphate content of $\sim 140 \mathrm{mg} / \mathrm{l}$. At the time of formation, the fan was graded to a base level that no longer exists. The fan is now perched above the axial valley floor and incised by deep gullies. An active landslide in the fan exposes its inner structure (Figure 8). The fan is composed of a thick alternation of massive travertine, laminated travertine, and detrital silty clays. Several faults parallel to the axial fault dissect the valley slope near the fan (Figure 6), and some outcrops exhibit normal fault planes of varying directions as illustrated by the fault population on Figure 3 . The normal faults on the northern flank of the valley could have a purely tectonic origin, in which case trans-tension is partitioned into east-west shearing along the axial strand and normal faulting away from it. Alternatively, the normal faults are generated by deep-seated gravitational spreading of a northern flank experiencing trans-pressional uplift. Since the Upper Miocene, the northern side of the Polochic fault is an area of uplift between the Polochic fault and the compressional structures of the Cuchumatanes Highs [GuzmánSpeziale and Meneses-Rocha, 2000; Guzmán-Speziale, 2010]. Shortening in 7 My deposits has been observed near Uspantán [Authemayou et al., 2011].

[42] Near the landslide, a $\sim 4 \mathrm{~m}$ high East-trending, Southdipping fault scarp straddles the fan surface (site 3, Figures 3, 6 , and $8 \mathrm{c}$ ). The corresponding fault is exposed along a northsouth oriented, $20 \mathrm{~m}$ high outcrop in one of the landslide scars (Figure 8a). Deformation during fan build-up is indicated by folded travertine layers that are eroded and sealed by a more recent, less deformed cap of inter-layered loam and travertine (Figures $8 \mathrm{a}$ and $8 \mathrm{~b}$ ). The cap is in turn displaced by the normal fault which disrupts the ground surface (Figure 8c).

[43] We imaged the fault by means of an ERT profile a few tens of meters west of the landslide scar (Figure 8d). North of the fault, a 5-m-thick conductive surficial layer 


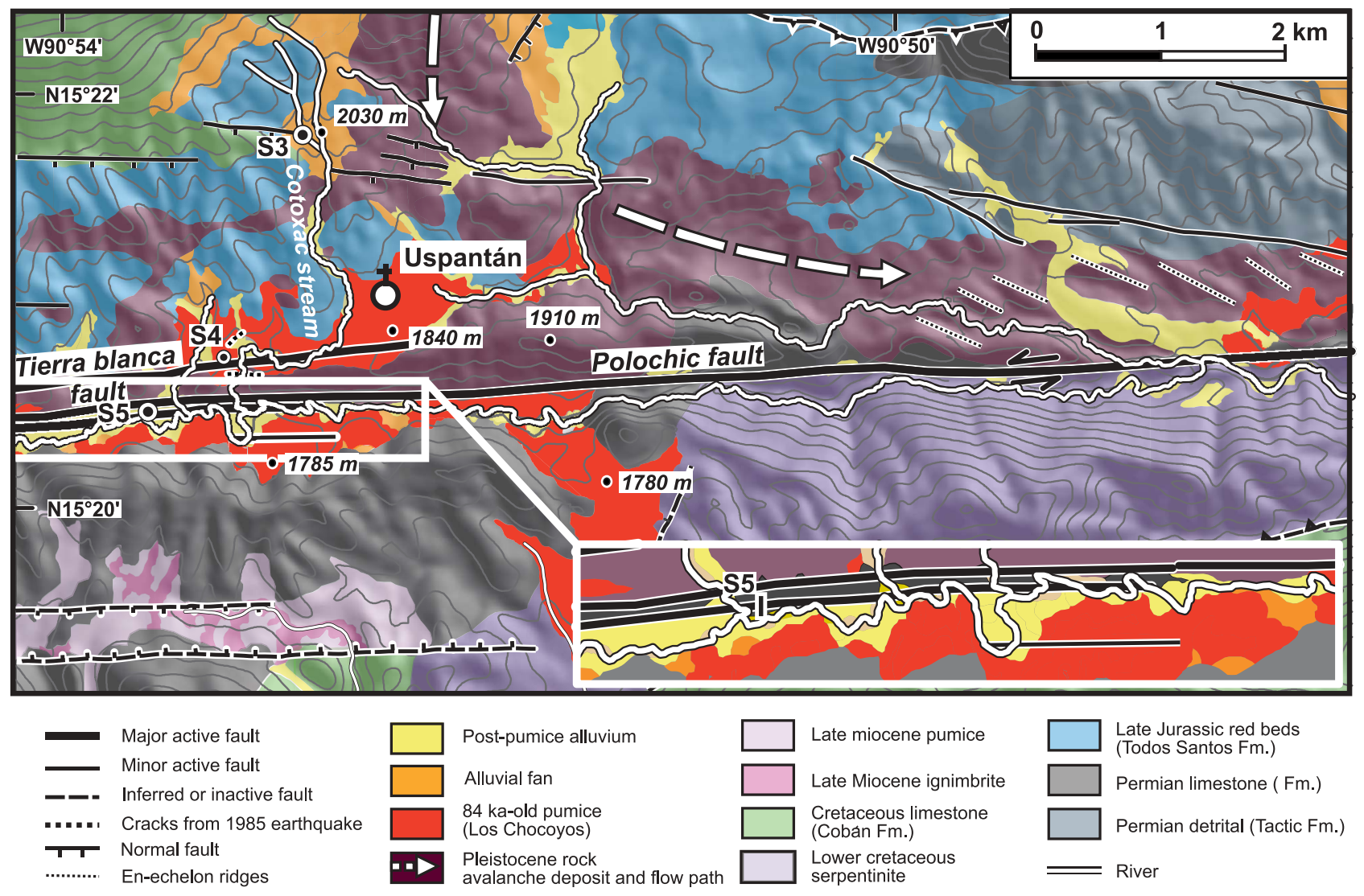

Figure 6. Geological map of the Uspantán region. Location shown on Figure 3.

$(10-20 \mathrm{Ohm} \cdot \mathrm{m})$, referred to as formation $\mathrm{A}$, is underlain by a moderately resistive material $(40-150 \mathrm{Ohm} \cdot \mathrm{m})$, referred to as formation $\mathrm{B}$. Through correlation with the outcrops in the landslide scar, we interpret formations A and B as the loam-dominated cap and the underlying deformed travertine, respectively. Formation $\mathrm{C}$, which underlies formation $\mathrm{B}$, exhibits low resistivities similar to formation $\mathrm{A}$ and hence may be composed of the same kind of loam-andtravertine sediment. Alternatively, it could correspond to the water-saturated zone within formation B.

[44] The normal fault that breaks the fan surface has no clear expression in the ERT image; however, at lateral distance of 60 to $80 \mathrm{~m}$ further north, formations $\mathrm{B}$ and $\mathrm{C}$ are disrupted by a $\sim 20 \mathrm{~m}$ wide, nearly vertical panel of moderate resistivity on the ERT profile (Figure 8d). We interpret this resistant panel as a fluid-cemented fault zone [e.g., EberhartPhillips et al., 1995; Holliger, 1996]. Indeed, we interpret a vertical offset of the base of formation B of up to $8 \mathrm{~m}$ across the anomaly, which could be of tectonic origin. Accordingly, the warping of formation $\mathrm{B}$ between horizontal coordinates 80 and $120 \mathrm{~m}$ may correspond to a drag fold in the downthrown block of the cemented fault. Formation $\mathrm{C}$ abuts the cemented fault and forms a $25 \mathrm{~m}$-thick wedge-like structure, suggesting that it was deposited as a syn-tectonic colluvial wedge on the hanging wall of the fault. The supposed fault zone is sealed by formation A, implying that this fault is older than the southern fault and was active during fan development.

[45] We suspect that the normal faults observed here are of tectonic origin, rather than a consequence of spreading in the course of fan uplift, because faulting started during the fan building phase, when the fan was still graded to the main valley floor and was still buttressed by the surrounding topography. Faulting continued after the end of the fanbuilding phase in association with other south-dipping normal faults, and the fan became progressively perched on the northern flank of the valley.

\subsubsection{Shortening-Related Vertical Displacements}

[46] The most conspicuous tectonic slice of the fault zone is located near the town of Uspantán. This $6 \mathrm{~km}$-long, $650 \mathrm{~m}$ wide, and $210 \mathrm{~m}$-high hill blocks the courses of northern tributaries before they can join the axial stream, and the northern tributaries are deflected east and the west around the ridge (Figure 6). The ridge is bounded to the south by the main trace of the Polochic fault and to the north by the Tierra Blanca fault, a branch crossing the center of Uspantán [Suski et al., 2010]. Indices of a reverse component of motion along the faults bounding the ridge permit to interpret the main ridge as a pressure ridge [Suski et al., 2010]. This interpretation is confirmed by observations made in a trench described hereafter. A magnitude 5.0 earthquake centered below the ridge destroyed the center of Uspantán on October 10, 1985, and opened long, deep cracks into the ridge crest (Figure 6). The ridge is made of rock avalanche deposits composed of Cretaceous limestone (Cobán Formation) that overlies Permian limestone (Chochál Formation).

[47] The oldest formation we can use to investigate the rate of ridge growth is the rock avalanche deposit. Its age is unknown, but the deposit predates the overlying 84-ky-old Los Chocoyos pumice [Drexler et al., 1980; Rose et al., 

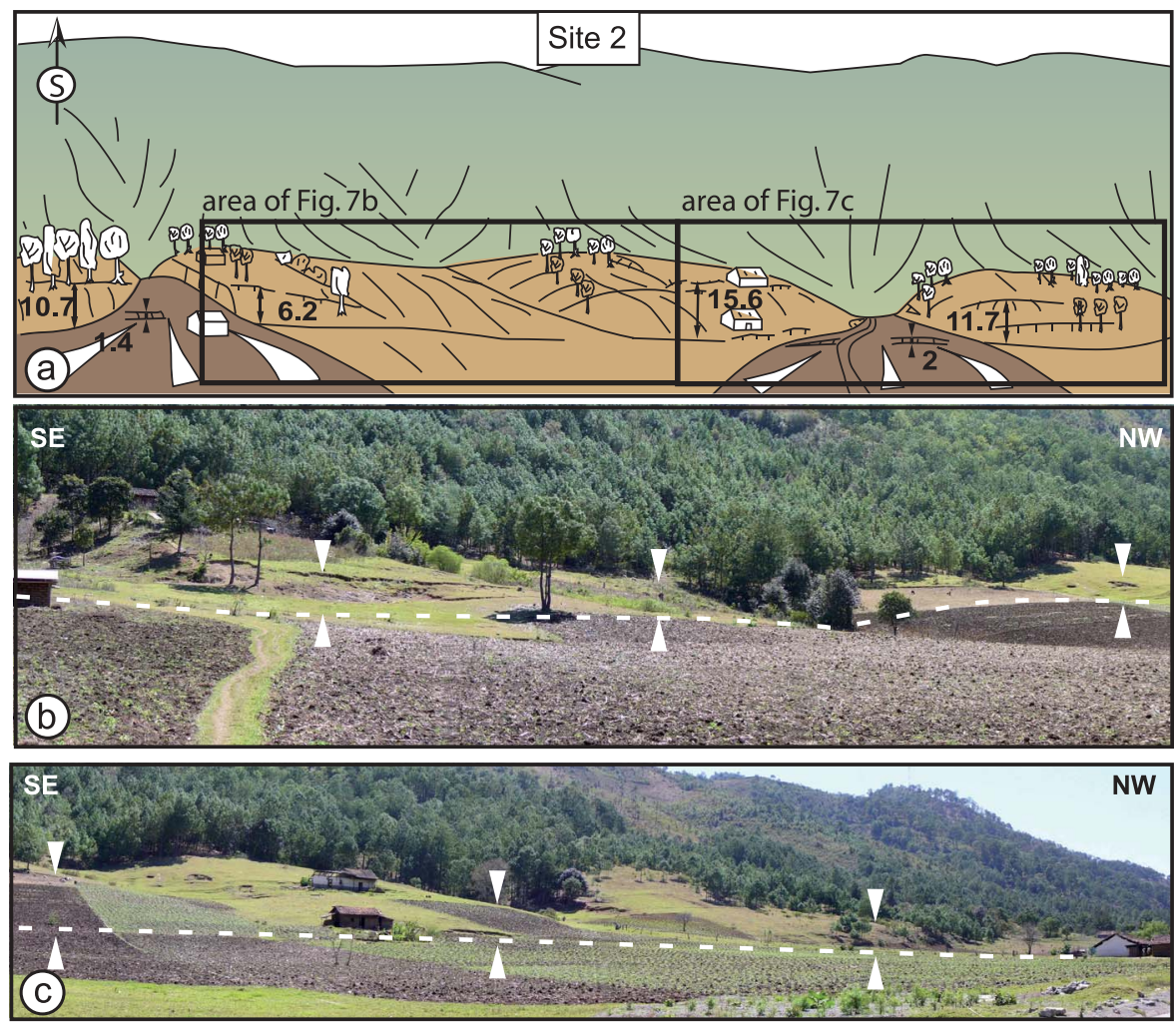

Figure 7. Normal fault scarp at site 2 (La Hacienda). (a) South looking sketch of fault scarps developed on two generations of alluvial fans above the western termination of the main segment of the Polochic fault of site 2 (Figure 3). Vertical offsets are indicated in meters. (b) View of scarps in the eastern region of site 2. White dashed line shows the fault trace. (c) View of scarp in the western region of site 2 . White dashed line shows the fault trace.

1987]. The avalanche originated north of Uspantán (Figures 3 and 6); it first flowed toward the south, but was then deflected by the southern valley flank. Most of the avalanche turned east, flowing downstream along the axial valley over a distance of 10-14 km. The eastern and western terminations of the ridge were buried below the avalanche deposits but not its central part, indicating that the ridge was already a topographic high at that time. The avalanche deposits were then incorporated into the ridge as it continued to grow. To the east, the avalanche deposit exhibits enechelon hills forming an east-west alignment (Figure 6). These features are neither erosional in nature nor primary topographic features of the avalanche flow. We interprete them as en-echelon senestral transpressive structures between the main fault and a northern WNW-ESE minor fault (Figure 6).

[48] The next formation affected by the pressure ridge is the Los Chocoyos pumice. ERT imaging in Uspantán has shown that the Tierra Blanca fault cuts through the pumice [Suski et al., 2010], and that the pumice laps onto the ridge with a slight rise of 10-14 m, which may be of tectonic origin. Faults with striations showing a reverse component of motion affecting the pumice are exposed west of Uspantán (site 4, Figure 3 ). The pumice flows came from the west, divided into two lobes astride the pressure ridge and proceeded further east all along the Polochic fault valley, down to the Chixóy River. The stream of Cotoxac is deflected west around the ridge (Figure 6). With pumice deposition, the stream course was displaced further east at the contact between the pumice fill and the part of the ridge still protruding above the pumice fill. The stream subsequently incised a new gorge across the ridge (Figure 6). Differential uplift across the main strand of the Polochic fault has since offset the surface of the pumice fill. The fill in Uspantan (1840 m, Figure 6) is higher than the pumice surface south of the Polochic fault (1780-1785 m, Figure 6), which implies a time-integrated vertical offset of $0.7 \mathrm{~mm} / \mathrm{y}$. The slightly higher pumice deposit lapping onto the ridge suggests that in the meantime the ridge was uplifted at a rate of $0.85 \mathrm{~mm} / \mathrm{y}$ with respect to the south side of the Polochic fault. Laterally, the pumice surface declines both to the east and to the west away of Uspantán and eventually stands only 20-30 m above the fill of the southern side of the Polochic fault. This means that the differential uplift near Uspantán is influenced by the presence of the ridge, and that the far-field difference in rock uplift across the Polochic fault is less than $0.24-0.36 \mathrm{~mm} / \mathrm{y}$.

[49] In detail, the main strand of the Polochic fault, south of the pressure -ridge, is composed of two parallel faults $\sim 70 \mathrm{~m}$ apart (Figure 6). The northern fault is flanked to the north by the main body of the ridge whereas the southern fault traverses the alluvial plain of the axial stream. This southern fault generates a 7-m-high, south-facing riser that treads the entire floodplain. The axial river is located south of the riser, but at three places the river has developed meanders across the riser. The meanders are systematically sheared, thus providing evidence of left-lateral displacement across the riser (Figure 6). 

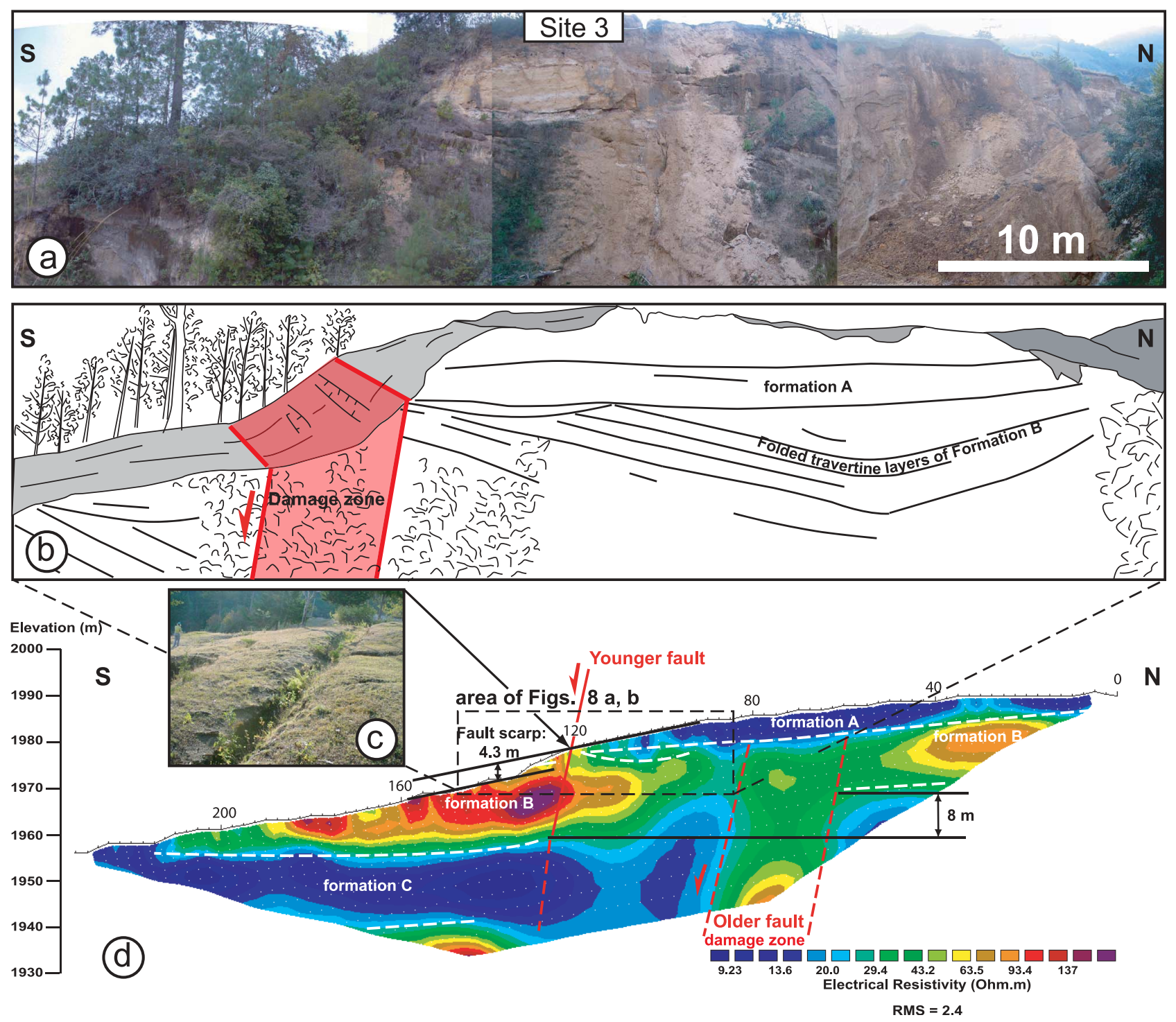

Figure 8. Geological and geophysical observations at site 3 (Cotoxac). (a) West looking view of Cotoxac landslide scar through the normal fault scarp affecting the alluvial fan (Figures 3 and 6). (b) Sketch of view showing the damage zone of the normal fault and bedding of the alluvial deposits. (c) View of cracks associated with the fault scarp on the alluvial fan surface. (d) ERT profile across the fault scarp of the Cotoxac alluvial fan produced near the landslide scar. Black dashed square indicates the location of the landslide scar view of Figure 8a. The red line shows the fault plane associated with the fault scarp affecting the alluvial fan. Black bold number indicated the vertical offset measurement in meters associated with this fault. Red dashed lines correspond to the inferred earlier fault planes and boundaries of associated damage zone. White dashed lines delineate the inferred boundaries between formations A, B and C.

[50] We excavated a 50-m-long trench across this riser at site 5 (Figure 6), which exposed a well-developed positive flower structure with a main vertical fault plane that separates pressure ridge material to the north from folded and faulted alluvial deposits to the south (Figure 9). The alluvial sediments rest on Los Chocoyos pumice flow deposits. For ease of description, the numbering of alluvial units increases with increasing depth and also from south to north. Below unit 1, which corresponds to the modern soil layer, the alluvial material in units 2 to 4 consists of an alternation of silty floodplain and sand-and-gravel channel deposits. The rust colored sediments were deposited by a northern tributary of the axial stream, which today is located west of the trench. The sediment load of units 2 to 4 consists predominantly of phyllosilicates, iron oxides, and potassium feldspar, and is almost exclusively derived from the Jurassic continental red beds of the Todos Santos Formation that outcrops in this tributary watershed. Units 2 to 4 also contain trace amounts of Los Chocoyos pumice.

[51] Alluvial unit 5 contains a much higher amount of pumice clasts $(\sim 90 \%)$, with more quartz and plagioclase in the fine sediment, which gives the formation its light gray color. Unit 6 corresponds to a group of very coarse channel deposits of Todos Santos origin in a coarse sandy matrix; 


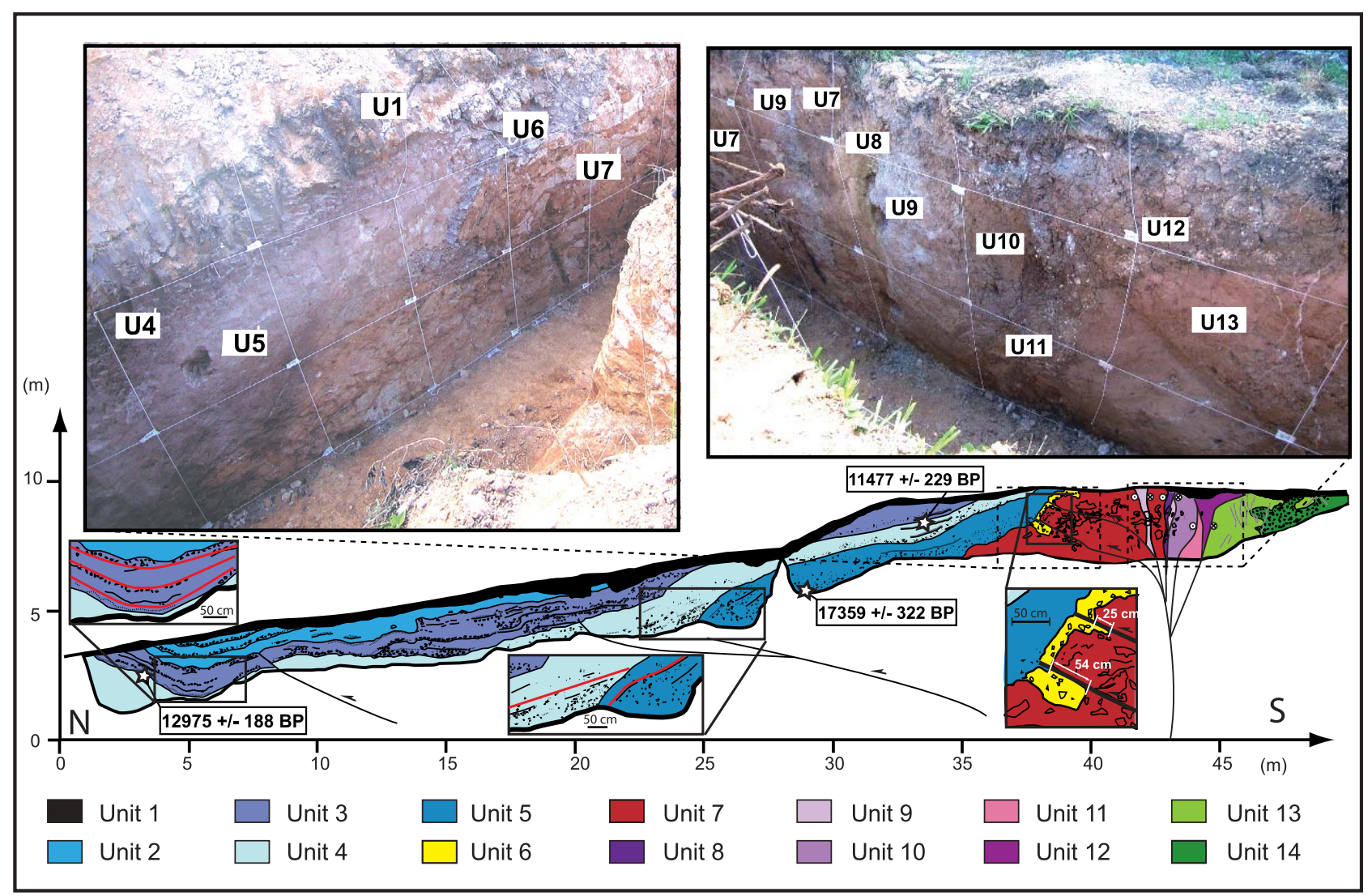

Figure 9. Log of trench wall at site 5 with two photographs revealing detailed of the main fault structure (Tierra Blanca-Pericón). Trench location is denoted on Figures 3 and 6. Encircled black numbers represents the unit name. Black numbers with black and white stars indicate the age and the location of the samples dated with radiocarbon analyses. Red lines point out global aspect of the strata geometry in units.

these channels incise the primary Los Chocoyos pumice of unit 7 , which typically contains numerous charred wood fragments. The deposits of unit 7 are faulted and weathered, with the formation of brown ocher clays associated with fluid circulation along fracture planes. The sedimentary package composed of units 2 to 7 is in vertical tectonic contact with the rock avalanche deposits of the ridge through a flower structure made of many allochthonous slices of various origins, such as pumice-derived gouges, gray clays, carbonates, and isolated pebbles of Todos Santos provenance (units 8 to 12). On the south of the rock avalanche, the flower structure overthrusts the salmon-pink unit 13 of old, consolidated, and unstructured alluvial deposits containing scarce red shale clasts and limestone grains in a sandy to silty matrix. Unit 13 also contains numerous dark nodules and many small vertical fractures filled with white calcite and laterally inter-fingers the colluvial debris of unit 14 that is derived from the avalanche deposits.

[52] The alluvial plain deposits are folded and tilted accommodating at least $8 \mathrm{~m}$ of differential uplift from the southern end of the trench to the central flower structure. The alluvial series (units 2-6) thickens southward suggesting that some of this differential uplift started during sediment deposition. From the axis of the flower structure down to the southern boundary of the trench, deformation takes the form of a south-verging asymmetric anticline that is separated by a $\sim 10$-m-long flat portion from a well-developed syncline; this syncline is associated with a minor reverse fault that is sealed by unit 2 at trench meter 8 . In the syncline, the lower part of U3 is more folded than the upper layers, thus providing evidence for syn-sedimentary folding. Along the intervening flat portion we suspect another minor north-dipping fault at trench meter 20 affecting U4 and sealed by U3. Further north, at trench meter 38, the pumice deposit (unit 7) and the overlying channels (unit 6) are strongly disrupted by two reverse faults rooting into the central flower structure, which are sealed by unit 5 .

[53] As a whole the trench reveals that the structure of the riser is that of an asymmetric positive flower structure, which propagates southwards into the alluvial plain and confirms that the ridge that backstops it to the north is a large pressure ridge. We dated detrital wood fragments in units 4 and 5. Samples were prepared for ${ }^{14} \mathrm{C}$ accelerated mass spectrometry and dated at the Poznan radiocarbon laboratory in Poland. The ${ }^{14} \mathrm{C}$ ages were corrected for state-of-the-art knowledge about changes in the atmospheric ${ }^{14} \mathrm{C} /{ }^{13} \mathrm{C}$ ratio over the last few millenia using $\mathrm{BCal}$, an online Bayesian radiocarbon calibration tool (http://bcal.shef.ac.uk). Sample ages are in stratigraphic order. Units 5, 4 base, and 4 top have radiocarbon ages of $14.29 \pm 0.08,11.13 \pm 0.06,9.98 \pm 0.06 \mathrm{ky} \mathrm{BP}$, which correspond to calibrated ages of $17.4 \pm 0.4,13.0 \pm 0.2$ and $11.5 \pm 0.2 \mathrm{ky} \mathrm{BP}$, respectively, with $95 \%$ certainty. Lack of soil development and erosive features indicates continuous sedimentation during this period. Uplift of floodplain 


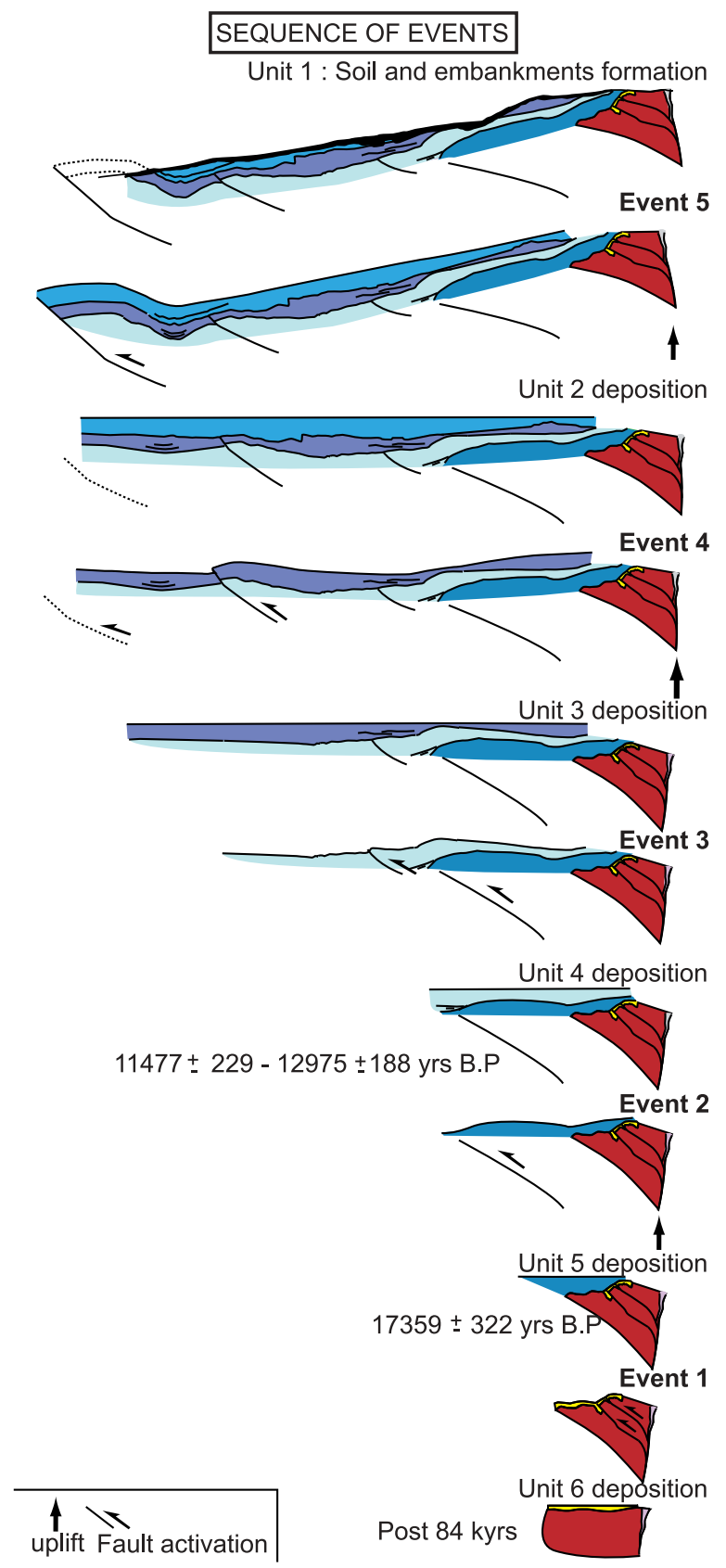

Figure 10. Inferred sequence of deformation and sedimentation at the trench of site 4 .

sediments proceeded incrementally after the deposition of unit 5 , but is not documented after deposition of unit 2. Assuming uplift has continued to present, the 10-m-high tilting of unit 5 and 8.6-m-high tilting of unit 4 since 17 and $11 \mathrm{ky}$ respectively, yield an average uplift rate of the riser of $0.7 \pm$ $0.1 \mathrm{~mm} / \mathrm{y}$. This rate is equal to the longer-term uplift rate of the pressure ridge over $84 \mathrm{ky}$ inferred from the offset of the pumice fill surface.

\subsection{Late Pleistocene Paleo-seismology}

[54] At least five rupture events are recognized in the trench (Figure 10). These events participated in the incremental widening of the Uspantán pressure ridge at the expense of the axial stream floodplain during the Late
Pleistocene. A first surface rupture E1 created the two reverse, north-dipping faults in units 6 and 7, which are sealed by unit 5 (trench meters 38-40, Figures 9 and 10). Their cumulative apparent displacement is $80 \mathrm{~cm}$ at the base of unit 6 (Figure 9) and associated with an uplift of $1.25 \mathrm{~m}$ of the flower structure. Rupture occurred between the deposition of the $\sim 84$ ky pumice of unit 7 and the deposition of unit 5 at $17.4 \pm 0.3 \mathrm{ky} \mathrm{BP}$ (Figure 10). The time elapsed between the deposition of units 7 and 6 is long, because over this period the valley floor underwent drastic changes in morphology with the removal of at least $40 \mathrm{~m}$ of pumice unit 7 before deposition of unit 6 . Over that period numerous ruptures produced some of the sub-vertical tectonic slices of the flower structure involving units 8 through 12 as documented by the presence of pumice fragments that are encountered in some of these units.

[55] The second recorded event E2 affected unit 5, but not unit 4 , and thus occurred after unit 5 deposition and prior to sedimentation of unit 4 , between $17.4 \pm 0.3 \mathrm{ky}$ and $13.0 \pm$ $0.2 \mathrm{ky}$ BP. The layers and upper surface in unit 5 are folded in a south-verging asymmetric anticline that probably lies above a south-verging blind thrust (trench meter 25, Figure 9). Above this fold, the beds of unit 4 overlap unit 5 with an angular unconformity as a result of the tilting of unit 5 before unit 4 deposition. Event E2 probably is a component of the flower structure movement, because there is an angular unconformity between unit 4 and unit 5 near the flower (Figure 9).

[56] Event E3 postdates the deposition of unit 4 and is therefore younger than $11.5 \pm 0.2 \mathrm{ky}$ B.P. E3 produced the fault affecting unit 4 , to the south of the anticline produced by E2 (trench meter 20, Figure 9). The fault scarp was eroded before deposition of unit 3 , as is evidenced by a change in sediment facies in unit 4 across the fault. Event E3 also reactivated the anticline formed during E2 because there is an angular unconformity between units 3 and 4 over the anticline (Figure 9). The northward thinning of unit 3 suggests a tilting of unit 4 during E3, prior to the deposition of unit 3, similar to the tilting of unit 5 during E2.

[57] Event E4 occurred during the sedimentation of unit 3 and is thus younger than $11.5 \pm 0.3 \mathrm{ky} \mathrm{BP}$. E4 activated a south verging thrust located $15 \mathrm{~m}$ to the south of the thrust that was activated during E3 (trench meter 8, Figures 9 and 10). This younger thrust displaced the base of unit 3 and was sealed by unit 2 . Deformation within the base of unit 3 is shown by thickening of the layers in the syncline to the south of the new thrust and by an upward decrease of strata dip within unit 3 (Figure 9). The presence of this syncline suggests the formation of another and deeper reverse fault at the time. This fault might intersect the ground surface south of the end of the trench (Figure 10). We suspect that E4 is also a component of the flower structure movement, because unit 3 is tilted near the flower.

[58] The last recorded event E5 accentuated the syncline formed during E4 folding of unit 2. Unit 2 rises toward the north, possibly as a result of an incremental uplift of the flower structure during E2 and many subsequent events, when sedimentation definitively shifted away from the flower structure and southward of the trench area. Shearing of the river meanders shows that compressional deformation was associated with horizontal displacement related to these earthquakes, but the induced lateral offset cannot be seen in a 
trench perpendicular to the fault. We do, however, show that the average uplift rate of the northern side is $\sim 0.7 \mathrm{~mm} / \mathrm{y}$. Left-lateral displacement along the Uspantán segment is probably similar to that the Chixóy segment previously estimated as $4.8 \pm 2.3 \mathrm{~mm} / \mathrm{y}$. If this long-term ratio between uplift and left-lateral displacement $(0.10-0.28)$ is representative of the average ratio achieved during a single rupture, then the horizontal rupture required to produce a $1.25 \mathrm{~m}$ increment of uplift, such as the one recorded during E1, has to be some $4.5-12.7 \mathrm{~m}$ long, the horizontal displacement being either accommodated on the same fault plane or along parallel lineaments. To what extent these ruptures have been generated by co-seismic slip or post-seismic creep is not known, but if the displacement is entirely co-seismic, then the corresponding earthquakes should have reached magnitudes 7.3-7.7 [Wells and Coppersmith, 1994] and would have involved several fault segments.

\section{Discussion}

\subsection{Strike-Slip Rate and History of the Polochic Fault}

[59] Based on marker offset and exposure dating we estimated a $4.8 \pm 2.3 \mathrm{~mm} / \mathrm{y}$ Holocene horizontal slip rate of the Polochic fault at site 1B (Figure 3). Previously, Holocene rates of up to $10 \mathrm{~mm} / \mathrm{y}$ had been proposed [e.g., Kupfer and Godoy, 1967], but these estimates were not constrained by any age dating. Our estimate is consistent with the results of a recent 4-year GPS monitoring period, which indicates that less than $\sim 5 \mathrm{~mm} / \mathrm{y}$ of inter-seismic displacement currently occurs across the Polochic Fault [Lyon-Caen et al., 2006]. The Polochic fault thus absorbs $12-35 \%$ of the $\sim 2 \mathrm{~cm} / \mathrm{y}$ plate motion between the Caribbean and North-American plates [DeMets et al., 2000; Guzmán-Speziale, 2010]. Within the given uncertainties, the inferred Holocene slip rate agrees with our previous estimates of $2.5-3.3 \mathrm{~mm} / \mathrm{y}$ of strike-slip over the last 7-10 My [Brocard et al., 2011]. Unless this agreement is coincidental, these estimates suggest that the lateral slip rate has been fairly constant since the Late Miocene. At this velocity $(2.5-7.1 \mathrm{~mm} / \mathrm{yr}), 19.3$ to $50.8 \mathrm{My}$ would be necessary to achieve the observed finite lateral offset of the fault of $132 \pm 5 \mathrm{~km}$ [Burkart, 1978, 1983]. An Eocene initiation of the fault is compatible with the known age of the Cretaceous-Eocene 'Laramide' folds displaced by the fault; the $10 \mathrm{Ma}$ initiation age proposed by Burkart [1994] for the Polochic fault is very unlikely. An Eocene initiation of the Polochic fault also coincides with the opening of the Cayman oceanic spreading center, which is clearly associated with the initiation of the modern Motagua fault [Rosencrantz et al., 1988; Pindell et al., 2005].

[60] A minimum age of fault initiation is provided by the opening of the lake Izabal pull-apart (Figure 1). It is unclear whether this releasing bend formed as early as the Polochic fault or later following a fault jog. In any case, its opening provides the latest possible age for the Polochic fault initiation and is marked by the deposition of the Late Miocene to Pliocene terrigenous Herreria Formation over the Middle Miocene Rio Dulce limestone [Carballo-Hernandez et al., 1988]. Initiation of the Polochic fault at the beginning of the Middle Miocene (15-16 My) has also been suggested by Burkart [1983] and Ratschbacher et al. [2009] using the offset of the Central American volcanic arc. If only $25 \mathrm{~km}$ of the $132 \mathrm{~km}$ displacement have been accommodated since
7-10 Ma [Brocard et al., 2011], and if the Polochic fault initiated at $19 \mathrm{Ma}$, then the fault must have initially moved at much faster rates of $8.5-12.4 \mathrm{~mm} / \mathrm{y}$. If the fault accommodated the whole of the $20 \mathrm{~mm} / \mathrm{y}$ plate motion before 7 $10 \mathrm{My}$, this would imply an initiation some $12-15.6 \mathrm{My}$ ago. It would be coeval to the temporary transpressional growth of the Tehuantepec Rise in the Cocos plate between 13 and 8 My [Manea et al., 2005].

[61] Such a rapid initiation followed by a decrease in slip rate is indeed a distinct possibility. A rapid onset of activity could result from a temporary locking of the Motagua fault. The Chuacús-Minas range, bracketed by the Motagua and the Polochic faults, was uplifted in the Middle to Late Miocene, before the locus of uplift shifted north of the Polochic fault in the Late Miocene [Brocard et al., 2011]. Deformation was then transpressional [Authemayou et al., 2011] and the Chuacús terrane has often been depicted as a restraining bend owing to the pronounced arcuate shape of the Motagua fault [e.g., Mann and Gordon, 1996]. The east-west trending Polochic fault would thus represent an alternative slipping plane, eliminating the stresses induced by the curvature of the Motagua fault, in case of stronger coupling across the plate boundary. Transtension was re-established between the Motagua and Polochic fault during the Pliocene [Authemayou et al., 2011], which would then coincide in time with this possible decrease in slip rate along the Polochic fault and a return of slip activity along the Motagua fault.

\subsection{Vertical Displacements Along the Polochic Fault}

[62] Transpressional uplift in the Sierra de Chama and the Cuchumatanes Highs north of the Polochic fault (Figure 1) probably results from the northward transfer of lateral slip from the Polochic fault to NE-SW trending reverse faults in the Cuchumatanes Highs [Authemayou et al., 2011]. Yet, transpressional structures along the Polochic fault seem to be confined to a few axial pressure ridges, such as the ridge of Uspantán (Figure 3). The $0.24-0.36 \mathrm{~mm} / \mathrm{y}$ far-field vertical slip rate measured in the Uspantán region, which implies a relative uplift of the northern part of the Polochic fault, may be a manifestation of the significant long-range uplift taking place north of the Polochic fault. Transtension is expected in the releasing bends of Lake Izabal, but it is also widely encountered along both the Uspantán and Chixóy regions. Extension could be triggered by the gravitational spreading of the uplifted block north of the fault. Indeed, numerous deep-seated landslides and rock avalanches affect the northern side of the fault zone. However, relief-induced spreading does not easily account for the occurrence of many normal faults in lower topographic positions. These faults more likely belong to a negative tectonic flower structure. This generic development of transtension along the Polochic fault is probably a consequence of the overall transtensional regime, which has spread through the Chuacús-Minas tectonic sliver since the Pliocene [Authemayou et al., 2011].

\subsection{Paleo-earthquake Recurrence and Magnitude}

[63] We found evidence for five surface-rupturing events in the trench at site 5 (Figure 3). These events all occurred in the past $84 \mathrm{ky}$ and four of them occurred during the past 17 $13 \mathrm{ky}$. The estimated inter-event time between E2 and E3 ranges between 1 and 6.5 ky thus giving a poorly constrained result. However, if we integrate the last four events, we 
obtain an average recurrence interval of 3.3-4.3 ky from E2 during the last 17-13 ky and a recurrence interval of 3.8-3.9 ky from E3 during the last $11.5 \mathrm{ky}$.

[64] Such recurrence intervals are much longer than the recurrence intervals suggested by the historic seismicity record, which provides a return period of 250-280 y for large earthquakes with magnitudes of 7.0 and higher and indicates that the next large earthquake is expected to occur before the end of the 21st century [White, 1984]. However, this return period is based on a total of three earthquakes, of which only two have reliable estimates of their magnitudes. Moreover, the association of these earthquakes with the Polochic fault still remains to be demonstrated. In any case, the order-ofmagnitude difference in the duration of the return period between the trench and historical seismicity records indicates that the former misses several events during the last 17-13 ky. This is not surprising, because the trench does not span the entire width of deformation zone and hence only provide a partial record of actual paleo-seismicity. In particular, the trench neither reaches the front of deformation of the flower structure, which is located a few tens of meters south of the trench, nor it intersects the Tierra Blanca fault that bounds the pressure ridge to the north. These parallel active traces distribute deformation and seismic activity. The events recorded in the trench, however, are clearly the products of large earthquakes and we estimate their magnitudes to be of order of 7.5, which is consistent with the magnitudes proposed for historical earthquakes [White, 1984].

\section{Conclusion}

[65] We have studied two regions of the Polochic fault with the aim of understanding their active tectonic structure and quantifying recent displacement rates. Quantitative geomorphic analyses and in situ-produced cosmogenic ${ }^{36} \mathrm{Cl}$ exposure dating of an alluvial fan surface provides the first direct geological estimate of Holocene left-lateral slip rate on the Polochic fault. The alluvial fan formed in several pulses between 10.3 and $3.9 \mathrm{ky}$, and yields a strike-slip rate of $4.8 \pm$ $2.3 \mathrm{~mm} / \mathrm{y}$ for the Chixoý part of the Polochic fault. These values are within the range of longer-term geological slip rates and short-term GPS-based estimates. Though possibly fortuitous, this consistency of fault slip rates over a wide range of timescales may indicate that the current partitioning of deformation over the Polochic and Motagua faults is representative of the deformation pattern over the last $7 \mathrm{My}$.

[66] Although the Polochic fault is dominantly strike-slip, displacement along the fault locally includes a substantial vertical component that is located on the main strand or partitioned on a series of splinters. Vertical slip is encountered along pressure ridges and along transtensional segments. Away from releasing bends, transtension is commonly observed and seems to be a manifestation of the regional, farfield stress regime rather than a consequence of local adjustments. Vertical offsets of a pumice surface since the last $84 \mathrm{ky}$ induce a far-field uplift rate of $0.24-0.36 \mathrm{~mm} / \mathrm{y}$ of the northern side of the fault. This motion component agrees with the compressional and the extensional tectonic regimes that characterize the regions north and south of the Polochic fault, respectively.

[67] A trench excavated on the side of a pressure ridge provides evidence of its progressive enlargement in the last
$17 \mathrm{ky}$ through four large paleo-earthquakes with magnitudes in excess of 7.0. These events indicate that the Polochic fault ruptures up to the surface during major earthquakes. It is thus highly probable that co-seismic surface displacements of several meters have occurred along the Polochic fault in 1538, 1785 and 1816 AD.

[68] Acknowledgments. This work was supported in part by the Swiss National Science Foundation (grants 200021-112175/1 and 200020-120117/ 1 to C.T. and G.B.). C.A. and B.S. were supported by postdoctoral assistantships from the University of Lausanne. We thank the many colleagues at the Universidad de San Carlos, Guatemala (USAC) and the Centro Universitario del Nordeste (CUNOR) who provided invaluable help during fieldwork. We acknowledge for the help during sample chemical preparation by Khemrak Pou, technician in the ${ }^{36} \mathrm{Cl}$ laboratory of CEREGE, Université Aix-Marseille 3, Aix-en-Provence, France. Thorough and constructive reviews by Tom Parsons (Editor), Randel Tom Cox, and Frank Audemard greatly helped to improve the quality of this paper.

\section{References}

Ambraseys, N. N., and R. D. Adams (2001), The Seismicity of Central America, A Descriptive Catalogue 1898-1995, 309 pp., Imp. Coll. Press, London.

Anderson, T. H., and R. J. Erdlac Jr., and M. A. Sandstrom (1985), LateCretaceous allochthons and post-Cretaceous strike-slip displacement along the Cuilco-Chixoy-Polochic Fault, Guatemala, Tectonics, 4, 453-475.

Andreani, L., X. Le Pichon, C. Rangin, and J. Martínez-Reyes (2008), Le bloc Sud mexicain: Principales limites et nouvelle estimation de son mouvement, Bull. Soc. Geol. Fr., 179, 209-223, doi:10.2113/ gssgfbull.179.2.209

Authemayou, C., G. Brocard, C. Teyssier, T. Simon-Labric, E. N. Chiquín, A. Guttierrez, and S. Morán (2011), The Caribbean-North AmericaCocos triple junction and the dynamics of the Polochic-Motagua fault system: A zipper model, Tectonics, 30, TC3010, doi:10.1029/2010TC002814.

Binley, A., and A. Kemna (2005), DC resistivity and induced polarization methods, in Hydrogeophysics, edited by Y. Rubin and S. Hubbard, chap. 5, pp. 129-156, Springer, New York, doi:10.1007/1-4020-3102-5 5.

Brocard, G., C. Teyssier, W. J. Dunlap, C. Authemayou, T. Simon-Labric, L. Chiquín, A. Guttierrez, and S. Morán (2011), Influence of vertical and horizontal displacements on drainage rearrangements along a strike-slip fault, Basin Res., 23(6), 631-651, doi:10.1111/j.1365-2117.2011.00510.x.

Bucknam, R. C., G. Plafker, and R. V. Sharp (1978), Fault movement (afterslip) following the Guatemala earthquake of February 4, 1976, Geology, 6(3), 170-173, doi:10.1130/0091-7613(1978)6<170:FMAFTG $>2.0 . C O ; 2$.

Burkart, B. (1978), Offset across the Polochic fault of Guatemala and Chiapas, Mexico, Geology, 6(6), 328-332, doi:10.1130/0091-7613(1978) 6<328:OATPFO $>2.0 . \mathrm{CO} ; 2$.

Burkart, B. (1983), Neogene north American-Caribbean plate boundary across northern Central America: Offset along the polochic fault, Tectonophysics, 99(2-4), 251-270, doi:10.1016/0040-1951(83)90107-5.

Burkart, B. (1994), Northern Central America, in An Introduction: Jamaica, Caribbean Geology, edited by S. Donavan and T. Jackson, pp. 265-284, Univ. of the West Indies Publ. Assoc., Kingston, Jamaica.

Caputo, R., S. Piscitelli, A. Oliveto, E. Rizzo, and V. Lapenna (2003), High-resolution resistivity tomographies in active tectonic studies. Examples from the Tyrnavos Basin, Greece, J. Geodyn., 36, 19-35, doi:10.1016/S0264-3707(03)00036-X.

Caputo, R., L. Salviulo, S. Piscitelli, and A. Loperte (2007), Late Quaternary activity along the Scorciabuoi Fault (southern Italy) as inferred from electrical resistivity tomographies, Ann. Geophys., 50, 213-224.

Carballo-Hernandez, M., N. L. Banks, J.-C. Franco-Austin, and L.-F. Lopez-Aguilar (1988), Cuenca Amatique, Guatemala: Una Cuenca Transtencional al Sur del Limite de Placas Norte America - Caribe, paper presented at Congreso Geológico Chileno, Soc. Geol. Chile, Santiago.

Carey, E. (1979), Recherche des directions principales de contraintes associées au jeu d'une population de failles, Rev. Geol. Dyn. Geogr. Phys., 21, 57-66.

Colella, A., V. Lapenna, and E. Rizzo (2004), High-resolution imaging of the High Agric. Valley Basin (southern Italy) with electrical resistivity tomography, Tectonophysics, 386, 29-40, doi:10.1016/j.tecto.2004.03.017.

Corbel, J. (1959), Erosion en terrain calcaire (vitesse d'érosion et morphologie), Ann. Geogr., 366, 97-120.

Danin, A., R. Gerson, and J. Garty (1983), Weathering patterns on hard limestone and dolomite by Endolithic Lichens and Cyanobacteria: Supporting evidence for eolian contribution to Terra Rossa soil, Soil Sci., 136(4), 213-217, doi:10.1097/00010694-198310000-00003. 
Deaton, B. C., and B. Burkart (1984), Time of sinistral slip along the Polochic fault of Guatemala, Tectonophysics, 102, 297-313, doi:10.1016/0040-1951(84)90018-0

DeMets, C., P. Jansma, G. S. Mattioli, T. H. Dixon, F. Farina, R. Bilham E. Calais, and P. Mann (2000), GPS constraints on Caribbean-North America plate motion, Geophys. Res. Lett., 27(3), 437-440, doi:10.1029/1999GL005436.

Dengo, C. A. (1982), Structural analysis of the Polochic fault zone in Western Guatemala, Central America, PhD thesis, Texas A\&M Univ., College Station.

Diaferia, I., M. Barchi, M. Loddo, D. Schiavone, and A. Siniscalchi (2006), Detailed imaging of tectonic structures by multiscale Earth resistivity tomographies: The Colfiorito normal faults (central Italy), Geophys. Res. Lett., 33, L09305, doi:10.1029/2006GL025828.

Dixon, T. H. (1993), GPS measurement of relative motion of the Cocos and Caribbean plates and strain accumulation across the Middle America trench, Geophys. Res. Lett., 20, 2167-2170, doi:10.1029/93GL02415.

Drexler, W. J., W. L. Rose, R. S. J. Sparks, and M. T. Ledbetter (1980), The Los Chocoyos Ash, Guatemala: A major stratigraphic marker in middle America and in three ocean basins, Quat. Res., 13(3), 327-345, doi:10.1016/0033-5894(80)90061-7.

Eberhart-Phillips, D., W. D. Stanley, B. D. Rodriguez, and W. J. Lutter (1995), Surface seismic and electrical methods to detect fluids related to faulting, J. Geophys. Res., 100, 12,919-12,936, doi:10.1029/94JB03256.

Erdlac, R. J., and T. H. Anderson (1982), The Chixoy-Polochic fault and its associated fractures in western Guatemala, Geol. Soc. Am. Bull., 93, 57-67, doi:10.1130/0016-7606(1982)93<57:TCFAIA >2.0.CO;2.

Franco, A., E. Molina, H. Lyon-Caen, J. Vergne, T. Monfret, A. Nercessian, S. Cortez, O. Flores, D. Monterosso, and J. Requenna (2009), Seismicity and crustal structure of the Polochic-Motagua fault system area (Guatemala), Seismol. Res. Lett., 80, 977-984, doi:10.1785/gssrl.80.6.977.

Gordon, M. B., and W. R. Muehlberger (1994), Rotation of the Chortis block causes dextral slip on the Guayape fault, Tectonics, 13(4), 858-872, doi:10.1029/94TC00923.

Gosse, J. C., and F. M. Phillips (2001), Terrestrial in situ cosmogenic nuclides: Theory and applications, Quat. Sci. Rev., 20, 1475-1560, doi:10.1016/S0277-3791(00)00171-2.

Guzmán-Speziale, M. (2010), Beyond the Motagua and Polochic faults: Active strike-slip faulting along the western North America-Caribbean plate boundary zone, Tectonophysics, 496(1-4), 17-27, doi:10.1016/j. tecto.2010.10.002

Guzmán-Speziale, M., and J. J. Meneses-Rocha (2000), The North AmericaCaribbean plate boundary west of the Motagua-Polochic fault system: A fault jog in southeastern Mexico, J. South Am. Earth Sci., 13, 459-468, doi:10.1016/S0895-9811(00)00036-5.

Hereford, R., K. S. Thompson, K. J. Burke, and H. C. Fairley (1996), Tributary debris fans and the late Holocene alluvial chronology of the Colorado River, eastern Grand Canyon, Arizona, Geol. Soc. Am. Bull., 108, 3-19, doi:10.1130/0016-7606(1996)108<0003:TDFATL>2.3.CO;2.

Holliger, K. (1996), Fault scaling and 1/f noise scaling of seismic velocity fluctuations in the upper crystalline crust, Geology, 24, 1103-1106, doi:10.1130/0091-7613(1996)024<1103:FSAFNS $>2.3 . C O ; 2$

Jordan, T. H. (1975), The present-day motions of the Caribbean Plate, J. Geophys. Res., 88, 3427-3434.

Kearey, P., M. Brooks, and I. Hill (2002), An Introduction to Geophysical Exploration, Blackwell Sci., Malden, Mass.

Kovach, R. L., and K. Nur (2006), Earthquakes and archeology: Neocatastrophism of Science?, Eos Trans. $A G U, 87(32)$, 317-318, doi:10.1029 2006EO320003.

Kupfer, D. H., and J. Godoy (1967), Strike-slip faulting in Guatemala, Trans. $A G U, 48,215$.

Lara, M. E. (1993), Divergent wrench faulting in the Belize southern lagoon: Implications for Tertiary Caribbean Plate movements and Quaternary reef distribution, AAPG Bull., 77(6), 1041-1063.

Leroy, S., A. Mauffret, P. Patriat, and B. Mercier de Lépinay (2000), An alternative interpretation of the Cayman trough evolution from reidentification of magnetic anomalies, Geophys. J. Int., 141, 539-557, doi:10.1046/j.1365-246x.2000.00059.x.

Lipfert, F. W. (1989), Atmospheric damage to calcareous stones: Comparison and reconciliation with experimental findings, Atmos. Environ., 23, 415-429, doi:10.1016/0004-6981(89)90587-8

Loke, M. H. (1999), RES2DINV Version 3.42, Geoelectrical Imaging 2D \& $3 D$ User Manual, Geotomo Software, Penang, Malaysia.

Loke, M. H., and R. D. Barker (1996), Rapid least-squares inversion of apparent resistivity pseudosections by a quasi-Newton method, Geophys. Prospect., 44, 131-152, doi:10.1111/j.1365-2478.1996.tb00142.x.

Lyon-Caen, H., et al. (2006), Kinematics of the North American-CaribbeanCocos plates in Central America from new GPS measurements across the
Polochic-Motagua fault system, Geophys. Res. Lett., 33, L19309, doi:10.1029/2006GL027694.

Macdonald, K. C., and T. L. Holcombe (1978), Inversion of magnetic anomalies and sea-floor spreading in the Cayman Trough, Earth Planet. Sci. Lett., 40(3), 407-414, doi:10.1016/0012-821X(78)90163-2.

Manea, M., V. C. Manea, L. Ferrari, V. Kostoglodov, and W. L. Bandy (2005), Tectonic evolution of the Tehuantepec Ridge, Earth Planet. Sci. Lett., 238, 64-77, doi:10.1016/j.epsl.2005.06.060.

Mann, P., and M. B. Gordon (1996), Tectonic uplift and exhumation of blueschists belts along transpressional strike-slip fault zones, in Subduction: Top to Bottom, Geophys. Monogr., vol. 96, edited by G. E. Bebout et al., pp. 143-154, AGU, Washington, D. C., doi:10.1029/GM096p0143

Massonnet, D., M. Rossi, C. Carmona, F. Adragna, G. Peltzer, K. Feigl, and T. Rabaute (1993), The displacement field of the Landers earthquake mapped by radar interferometry, Nature, 364, 138-142, doi:10.1038/ $364138 \mathrm{a} 0$

Matsushi, Y., K. Sasa, T. Takahashi, K. Sueki, Y. Nagashima, and Y. Matsukura (2010), Denudation rates of carbonate pinnacles in Japanese karst areas: Estimated from cosmogenic $36 \mathrm{Cl}$ in calcite, $\mathrm{Nucl}$. Instrum. Methods Phys. Res., Sect. B, 268(7-8), 1205-1208, doi:10.1016/j. nimb.2009.10.134.

Nguyen, F., S. Garambois, D. Chardon, D. Hermitte, O. Bellier, and D. Jongmans (2007), Subsurface electrical imaging of anisotropic formations affected by a slow active reverse fault, Provence, France, J. Appl. Geophys., 62, 338-353, doi:10.1016/j.jappgeo.2007.03.003.

Peterson, J. A. (1982), Limestone pedestals and denudation estimates from Mt Jaya, Irian Jaya, Aust. Geogr., 15, 170-173, doi:10.1080/ 00049188208702812

Pindell, J., L. Kennan, W. V. Maresch, K.-P. Stanek, G. Draper, and R. Higgs (2005), Plate-kinematics and crustal dynamics of circum-Caribbean arccontinent interactions in tectonic controls on basin development in proto-Caribbean margins, Spec. Pap. Geol. Soc. Am., 394, 7-52.

Plafker, G. (1976), Tectonic aspects of the Guatemala earthquake of 4 February 1976, Science, 193, 1201-1208, doi:10.1126/science.193.4259.1201.

Priesnitz, K. (1974), Losungsraten und ihre geomorphologische Relevanz, Abh. Akad. Wiss. Göttingen, Math. Phys. Kl., 3(29), 68-84.

Ratschbacher, L., et al. (2009), The North American-Caribbean plate boundary in Mexico-Guatemala-Honduras, Geol. Soc. Spec. Publ., 328 , 219-293, doi:10.1144/SP328.11.

Reddy, M. M. (1989), Acid rain damage to carbonate stone: Aquantitative assessment based on the aqueous geochemistry of rain fall runoff from stone, Earth Surf. Processes, 13, 335-354

Reilinger, R. E., et al. (2000), Coseismic and postseismic fault slip for the 17 August 1999, M=7.5, Izmit, Turkey earthquake, Science, 289 , 1519-1524, doi:10.1126/science.289.5484.1519.

Rizzo, E., A. Colella, V. Lapenna, and S. Piscitelli (2004), High-resolution images of the fault-controlled High Agric. Valley basin (southern Italy) with deep and shallow electrical resistivity tomographies, Phys. Chem. Earth, 29, 321-327, doi:10.1016/j.pce.2003.12.002.

Rose, W. I., C. G. Newhall, T. J. Bornhorst, and S. Self (1987), Quaternary silisic pyroclastic deposits of Atitlán caldera, Guatemala, J. Volcanol. Geotherm. Res., 33, 57-80, doi:10.1016/0377-0273(87)90054-0.

Rosencrantz, E., M. I. Ross, and J. G. Sclater (1988), The age and spreading history of the Cayman trough as determined from depth, heat flow, and magnetic anomalies, J. Geophys. Res., 93, 2141-2157, doi:10.1029/ JB093iB03p02141

Schimmelpfennig, I., L. Benedetti, R. Finkel, R. Pik, P.-H. Blard, D. Bourlès, P. Burnard, and A. Williams (2009), Sources of in-situ $36 \mathrm{Cl}$ in basaltic rocks. Implications for calibration of production rates, Quat. Geochronol., 4, 441-461, doi:10.1016/j.quageo.2009.06.003.

Schwartz, D. P., L. S. Cluff, and T. W. Donnelly (1979), Quaternary faulting along the Caribbean-North America plate boundary in Central America, Tectonophysics, 52, 431-445, doi:10.1016/0040-1951(79)90258-0.

Smith, D. I., and T. C. Atkinson (1976), Process, landforms and climate in limestone regions, in Geomorphology and Climate, edited by E. Derbyshire, pp. 369-409, John Wiley, London.

Stein, S., C. DeMets, R. G. Gordon, J. Brodholt, D. Argus, J. F. Engeln, P. Lundgren, C. Stein, D. A. Wiens, and D. F. Woods (1988), A test of alternative Caribbean plate relative motion models, J. Geophys. Res., 93, 3041-3050, doi:10.1029/JB093iB04p03041.

Stone, J., G. L. Allan, L. K. Fifield, J. M. Evans, and A. R. Civas (1994), Limestone erosion measurements, with cosmogenic chlorine-36 in calcite: Preliminary results from Australia, Nucl. Instrum. Methods Phys. Res., Sect. B, 92, 311-316, doi:10.1016/0168-583X(94)96025-9.

Stone, J. O., G. L. Allan, L. K. Fifield, and R. G. Cresswell (1996), Cosmogenic chlorine-36 from calcium spallation, Geochim. Cosmochim. Acta, 60, 679-692, doi:10.1016/0016-7037(95)00429-7.

Stone, J. O., J. M. Evans, L. K. Fifield, G. L. Allan, and R. G. Cresswell (1998), Cosmogenic chlorine-36 production in calcite by muons, 
Geochim. Cosmochim. Acta, 62, 433-454, doi:10.1016/S0016-7037(97) 00369-4.

Suski, B., G. Brocard, C. Authemayou, B. Consenza Muralles, C. Teyssier, and K. Holliger (2010), Localization and characterization of a seismically active fault in an urbanized area in central Guatemala by means of geoelectrical imaging, Tectonophysics, 480, 88-98, doi:10.1016/j.tecto.2009.09.028.

Suzuki, K., S. Toda, K. Kusunoki, Y. Fujimitsu, T. Mogi, and A. Jomori (2000), Case studies of electrical and electromagnetic methods applied to mapping active faults beneath the thick quaternary, Eng. Geol., 56, 29-45, doi:10.1016/S0013-7952(99)00132-5.

Sykes, L. R., W. R. McCann, and A. L. Kafka (1982), Motion of Caribbean plate during last 7 million years and implications for earlier Cenozoic movements, J. Geophys. Res., 87, 10,656-10,676, doi:10.1029/ JB087iB13p10656.

Wells, D. J., and K. J. Coppersmith (1994), New empirical relationships among magnitude, rupture length, rupture width, rupture area, and surface displacement, Bull. Seismol. Soc. Am., 84(4), 974-1002.
White, R. A. (1984), Catalog of historic seismicity in the vicinity of the Chixoy-Polochic and Motagua faults, Guatemala, U.S. Geol. Surv. Open File Rep., 84-88.

White, R. A. (1985), The Guatemala earthquake of 1816 on the ChixoyPolochic fault, Bull. Seismol. Soc. Am., 75, 455-473.

White, R. A., and D. H. Harlow (1993), Destructive upper-crustal earthquakes of Central America since 1900, Bull. Seismol. Soc. Am., 83(4), 1115-1142.

Wise, D. J., J. Cassidy, and C. A. Locke (2003), Geophysical imaging of the Quaternary Wairoa North Fault, New Zealand: A case study, J. Appl. Geophys., 53, 1-16, doi:10.1016/S0926-9851(03)00013-2.

Witt, C., C. Rangin, L. Andreani, N. Olaez, and J. Martinez (2012), The transpressive left-lateral Sierra Madre de Chiapas and its buried front in the Tabasco plain (southern Mexico), J. Geol. Soc., 169, 143-155, do1:10.1144/0016-76492011-024. 